Радоје Д. Симић

Филолошки факултет

Универзитет у Београду
УДК 811.163 .41 '366.58

ДОИ https://doi.org/10.18485/ai_

lik.2016.2.3.4

\title{
ВИД И/ИЛИ АСПЕКТ - ЛЕКСИЧКОСЕМАНТИЧКА(/Е) И/ИЛИ ОБЛИЧКОСЕМАНТИЧКА(/Е) КАТЕГОРИЈА(/Е)?
}

Повод за овај рад била су неусаглашена схватања о глаголском виду, одн. аспекту, која се огледају на једној страни у 'пунктуалној', а на другој у 'комплетивистичкој' теорији вида, - као и неразјашњени односи словенског вида, са лексикализованим статусом опозиција, и факултативним 'аспекатским’ дистинкцијама зависним од контекста у нпр. западним европским језицима. Непосредан подстицај за расправу о виду нашли смо у изјавама најновијих проучавалаца значења српског аориста и имперфекта. Но бар узгред било је потребно дотаћи се учења о 'аспектологији', и у новије време 'акционалности' словенскога глагола. Изложићемо најзначајнија схватања томе и покушати да их саберемо у јединствено схватање о виду и/или аспекту.

Клучне речи: вид, аспект, пунктуалност, комплетизам, глобализам, аорист, имперфекат, перфективан, имперфективан.

\section{1. Увод: о глаголском виду у српском језику и питању 'аспекта'}

1. А. Белић се више пута враћао проблему глаголског вида. Изложићемо у овом поглављу његова испитивања у посебним студијама. Једном приликом он је изразио мишљење да ваља разликовати два типа значења обухваћена нашим термином 'глаголски вид'. „Прво ја називам просто видом, а друго - секундарним или изведеним глаголским видом. Ако вид назовемо Aspekt (= Aktionsart), онда би изведени глаголски вид био abgeleiteter Aspekt... или sekundärer 
Aspekt... aspect primaire и aspect dérivé. Мислим да не би било згодно за ово друго употребљавати назив Zeitart и сл. јер он не би одговарао његову смислу“ (Белић 1998: 266). Белић при том мисли на разлику између простих или по њему 'правих' глаголских речи и њиховог лексичког видског значења ('рећи' према 'говорити' или сл.), и 'неправих' речи ове врсте - тзв. перфектизованих и имперфектизованих ('ићи' - 'прићи' - 'прилазити' и др.). А не помиње овде као проблем оно о чему касније опширно расправља - нпр. разлику између словенске видске системе и 'факултативног вида' оних језика који нешто од видских знечења познају искључиво на нивоу односа белићевих 'примарних' дистинкција, и оне се главнином испољавају на плану контекстне варијације у реченици. Ми ћемо се у овом раду осврнути на поменуте проблеме, и покушати да их расправимо у узајамној конфронтацији.

2. О посебностима 'факултативног вида' у лингвистици западних језика суди се често по угледу на 'систем глаголског вида' у словенским језицима, као на несистематизовано значење које се испољава у самој употреби језика, или се та категорија занемарује, као лингвистички ирелевантна.

2.1. У старијој граматичкој литератури нпр. Херман Паул, у својој чувеној 'Немачкој граматици' (Паул 1958: IV, 65-67), проблеме глаголског вида (Aktionsart) излаже у ослонцу на словенску науку о виду. Али нека његова запажања тичу се управо специфичнсти немачког аспекта, те свакако заслужују да их размотримо:

Имперфективан је глагол када означава радњу у процесу, у њеном току; перфективан када се односи на један моменат, то јест на завршетак догађања или на почетак неког стања. Многи глаголи могу бити како перфективни тако и имперфективни, други су пак по правилу једно или друго. Имперфективни су нпр. liegen, schlafen, wohnen, leben [лежати, спавати, становати, живети] ${ }^{1}$, перфективни

1 Паул не помиње да у словенским језицима према овима стоје 'секундарни' перфективни гл. 'полежати', 'належати се', те 'испавати се', 'успавати се'; 'поживети', 'доживети' итд. 
kommen, bringen, finden, sterben [доћи, донети, наћи, умрети $]^{2}$, и нарочито многи сложени глаголи [нпр. entkommen, verbringen, abfinden, beiwohnen, aussterben]. Ипак, врло често долази до преласка једног вида у други. Тако нпр. er kommt може се рећи кад се неко управо приближава [исп. српски 'он долази'], и тада је глагол имперфективан. На својој страни, gehen [ићи], кад недостаје упућивање на почетак или крај, има имперфективни карактер..., али може се употребљавати и са перфективним смислом.

Паул у дефиницији вида заступа теорију која се обично именује 'пунктуалном' (боље 'пунктуалистичком'): имперфективност је необележена, а перфективност се препознаје по неком ограничењу 'трајања радње', по Паулу на почетку или крају означеног 'догађања или стања'. Његови примери, међутим, ако је судити у поређењу према нашим преводима, заправо су семантички неодређени што се тиче 'почетног' и 'завршног' ограничења: kommen, bringen, - кад их посматрамо у односу према 'доћи', 'донети', - означавају заправо целовит догађај, док српски еквиваленти инсистирају на завршном моменту догађања (које му претходи као позадински семантички присенак). У односу finden, sterben према 'наћи', 'умрети' једнакост значења нешто је извеснија јер 'наћи' не тако јасно, или боље речено: скоро никако не упућује на претходно 'тражење', као ни 'умрети' на 'мрење'. Права еквиваленција заступљена је у односу српских простих перфективних глагола и њихових парова у немачком, нпр. 'пасти' према fallen или 'пући' према platzen или сл. Не заборавимо, међутим, Паулову мисао о факултетивности немачког вида, те да fallen значи и 'падати', a platzen и 'пуцати' (као уосталом што и abfallen значи 'отпасти' и 'отпадати', aufplatzen 'pacпући се' и 'распуцати се') ${ }^{3}$ итд. Вид је у немачком, видимо, само делимично, у малој мери 'лексикализован', својствен

2 У српском је само 'црћи' примарно перфективан (према њему стоји секундарни имперфективни 'цркавати') док су 'доћи', 'донети' и 'наћи' секундарни сложени са префиксима, а према њима стоје примарни прости гл. 'ићи', 'носити' итд.

3 Облик 'распуцати се' ('распуцати се', РМС, значи нешто друго) опомиње нас на чињеницу да језички систем није компактан, тј. да су у њему могућа празна места. 
глаголској основи, док је по правилу препознатљив у употреби, а није, или најчешће није својство глаголске лексеме као такве.

2.2. У новије време, каткада чак ни у радовима оних западних стручњака који велику пажњу посвећују прагматици језика, дакле употребним вредностима језичких јединица 'у акцији', не узима се у разматрање проблем вида ни аспекта (в. нпр. Енгел 1988, где се уопште не помиње ни Aspekt ни Zeitart или сл.).

2.3. Али мимо тога, и насупрот томе, јевљају се теоријске расправе које покрећу нова питања о глаголским значењима вида и сродних појава, и на нов начин их разрешавају (в.: Комри 1976). Зачетником новије словенске 'аспектологије' (тј. 'акционалности': Поповић 2007: 37) сматра се А. В. Исаченко (1960), а за њим долазе Ј. Маслов $(1962,1965)$, А. Бондарко $(1971,1984)$ и др. За разлику од Белићевих, идеје осталих истраживача засноване су на поставкама о категорији коју немачки теоретичари називају Aktionsart ('врсте радњи', руски 'способы глагольного действия').

3. А. Белић, рекосмо, заступа став о искључиво 'лексичком’ и 'лексичко-творбеном' карактеру словенског, и српског глаголског вида, за разлику од времена, које је синтаксичка категорија: „...свако глаголско време одређује [се] према извесном моменту, а глаголски вид је апсолутан, дат у самој основи глагола“ (JФ XIII, 1933-1934, 225; в. и: Стевановић 1991: 530). Белићева дефиниција вида није у целини тачна (Вид ни у српском није искључиво „дат у самој основи глагола“). А није тачна ни дефиниција времена. Наиме Белић не узима у обзир да и временски облици чине систем, не додуше лексички или 'лексичко-граматички' (у чијој су основи творбени механизми), али систем - морфолошки, скуп корелативних облика међу којима делује мрежа дистинкција (провизорно узевши то су дистинкције садашњост-прошлост, садашњост-будућност итд.).

3.1. И Белић (1998: 260) налази друкчије стање у несловенским језицима него у словенским; тамо су видске корелације факултативне, према обавезности словенског вида. Наиме, у несловенским језицима - 
...глаголски вид није морфологисан, није саставни део глаголске основе..., - може и глагол са природним перфективним значењем добивати у реченици и имперфективно значење и, обрнуто, имперфективни глаголи по природи својој могу, под нарочитим условима у реченици, добивати перфективно значење. Напр...: Regardez les feuilles qui tombent = 'Гледајте лишће које пада'. У француском је употребљено tombent у имперфективном значењу, и то није ничим нарочито показано до значењем у реченици; међутим у српскохрватском, и у свима другим словенским језицима, употребиће се за то нарочити облик основе имперфективног вида, који се може употребљавати уместо tombent једино и искључиво кад реченица тражи иперфективно значење. Француско tomber може се употребити и у перфективном значењу: Si tu tombes de set escalier, tu te fera mal = 'Ако паднеш са ових степеница, убићеш се'. У промењеној ситуацији, која претпоставља тренутно извршење глаголске радње, - у српскохрватском се језику не би могао више употребити облик 'падаш', већ би се морао употребити облик 'паднеш', чије једино значење перфективно. Међутим у француском је употребљен исти облик tombes.

Beћ се накупило довољно чињеница на основу којих је могуће извести прелиминарни закључак. Наиме, видимо да је оправдано говорити о двема категоријама, а не о једној: једно је словенски вид, систематичан и својствен - за сада ћемо рећи искључиво - глаголској основи; друго је аспект несловенских језика, несистематизована, или ндовољно систематизована категорија испољива пре на нивоу глаголске употребе него глаголских лексема.

3.2. Словенски глаголски вид по Белићу је изводљив, и изведен је из индоевропске системе, из које су директно настали и аспекти западних језика - и у којој је сваки глагол могао према приликама у реченици добити перфективно или имперфективно значење. Он то за ову прилику показује на примеру немачког језика:

У општим или, боље да речем, најопштијим цртама..., немачки нам језик даје још и данас извесну претставу о томе. У реченици Die Sonne geht auf = 'Сунце се рађа (диже)' или сл. имамо презент са префиксом који је прилошки употребљен; 
у реченици Die Sonne ist aufgegangen = 'Сунце се родило (дигло) ${ }^{4}$ или сл. имамо перфекат са префиксом и са перфективним значењем или са резултативним (претеритопрезентским) значењем: 'Сунце је високо (дигнуто)'.

Индоевропски је садржао и базу за развој словенског вида. Јер тамо наиме: „...претеритална времена, и то аорист и перфекат, могла су на основу самог односа префикса према претериталној радњи значити да је радња извршена и ограничена на онај начин како то префикси траже својим значењем“ (Белић 1998: 263). На неки начин, како изгледа, словенски префикси су ти који чине спону са овако оцртаним стањем у индоевропском, док је ширење видских корелација са префиксираних на просте глаголе, заправо ствар одвојеног развоја словенског глагола. Белић (1998: 266) своју анализу закључује управо мислима о тим сложеним генетским питањима, и двојној природи словенског вида с тим у вези; али код њега је генетика и хијерархија обрнуто схваћена:

Према свему изнесеном било би потребно одвојити засебним називом значење основног словенског глаголског вида како се он јавља у трајних и перфективних глагола од оног значења глаголског вида које се јавља у имперфектизованих и перфектизованих глагола. Прво ја називам просто видом, а друго - секундарним или изведеним глаголским видом. Ако вид назовемо Aspekt (= Aktionsart), онда би изведени глаголски вид био abgeleiteter Aspekt... sekundärer Aspekt, aspect primaire et aspect dérivé или сл. ${ }^{\text {"5 }}$

Префиксални перфективни глаголи схваћени су код Белића као посебна поткатегорија, између осталог и по томе што су условно лексикализована скупина форми (како изгледа, по свој прилици и изведени имперфективни глаголи). Чисте видске дистинкције на лексичком плану јављају се само код простих глаголских речи. Горња разлагања

4 У прецизнијем преводу немачки примери значе: Сунце излази Сунце је изашло.

5 Белић мисли „да би било згодно за ово друго употребљавати назив Zeitart и сл. јер он не би одговарао његову смислу“. 
о пореклу 'чистих' дистинкција како су код Белића схваћене (неограниченост трајања према ограничености радње моментом почетка или краја) показују у ствари да су оне својствене само префиксалним твореницама. Код простих глагола видска значења су друкчија - у даљој дискусији видећемо заправо какава су - и друкчије су уређена.

3.3. Белић (2000: 414-415) разлику измећу индоевропског и словенског вида налази у томе што је потоњи, како рекосмо, 'систематизован', за разлику од првог, који нема системски карактер. Белић се о томе заправо колеба, али неке изјаве иду у правцу како смо га оцртали:

Видска значења имају сви индоевропски језици, а видске системе немају.

Видска су значења она која глаголи имају према стварном значењу своме, било самостално употребљени било употребљени у реченици. У совенским су језицима на првом месту такви прости неизведени глаголи, на пр. плести, звати, прати, писати итд.

Њихово је значење трајно, али то трајно значење није добивено неким нарочитим формантом; оно је у природи самих глагола, јер се њихова радња - по природи својој може вршити дуже или краће време. Тако исто глаголи пасти, сести, дићи, стати итд. тренутни су опет по природи самих значења глагола; ми их називамо видским значењима зато што она остају у словенским језицима у свима облицима и у свима временима исти, тј. или су трајна или су тренутна. Међутим у другим индоевропским јзицима оба значења, и трајности и тренутности, могу зависити код истог глагола од његове употребе. На пр. у француском језику, у реченици на питање que fais tu? можемо добити имперфективни глагол као одговор: je jette les piéres dans la fosse, српскохрватски ‘ја бацам камење у јарак'; али у другој реченици може исти глагол имати перфективно значење: et puis je jette la piére dans l'eau - 'И затим ја бацим камен у воду'. Или на пр. у перфекту: j’ai jeté la piére dan l'eau има перфекат такође свршено значење 'ја сам бацио камен у воду'.

Анализа је потпуно тачна, али уз њу су потребне две напомене. 
Прва се тиче лексичке перфективности, тј. глагола типа пасти, сести, дићи, рећи и сл. према нпр. стати, дати, маћи, таћи итд. Белић говори о 'природном' виду тих глагола, јер они увек значе кратку радњу. Међутим, међу нашим примерима у томе нема једнакости. Глаголи друге групе и стварно су тренутни, док први практично у себи крију дуже или краће трајање радње, управо попут имперфективних глагола; али то је трајање на семантичкој равни потиснуто у позадину, а у првом плану су граничне тачке трајања, које се представљају као једна јединствена.

Друга напомена тиче се употребне неутрализације имперфективних глагола, које се најочигледније код нпр. 'драмског презента': „И затим ја бацам камен у воду и одлазим“, - а и другде - где презент има перфективни смисао, јер обележава једнократну перфективну радњу. Видска неутрализација подсећа на видско колебање глагола у несловенским језицима, и упућује најпре на извесно несавршенство, а затим на недовршеност система глаголског вида, и могућност неутрализације основног значења под притиском контекста.

3.4. „Као што се одавде види - мисли Белић, што се може прихватити као општи глобалан став, уз занемаривање појединости, - данашњи словенски вид само је стварно или објективно значење глаголске основе којему одговара различно синтаксичко значење других језика“б. Рекосмо да практично ствар стоји мало друкчије. Али остављамо за сада подробности по страни, а навешћемо Белићево размотрање развоја словенског вида из претпостављене индоевропске ситуације, и природе словенског вида у вези с тим. Белић једном приликом (2000: 416) о томе износи специфично мишљење, које се не слаже са општим схватањем иначе изношеним:

[Лексичка видска значења не чине систем, јер] свако од тих значења зависи од природе значења глагола; међутим - као

6 Подробнију расправу о виду в. код С. Агрела и Ђ. Грубора (1953). В. такође и М. Стевановића (1991: 528 и д.), као и литературу тамо наведену (стр. 530). 
што је и природно, пошто су то два засебна и различна значења - сама та значења не налазе се међусобно ни у каквом односу... Чак ако узмемо и блиске по значењу глаголе: седети и сести, и они се не находе ни у каквом видском односу: сести значи 'заузети место за седење', 'спустити се на предмет за седење' или слично, а седети значи 'вршити радњу седења'; сести значи 'извршити потребан чин за седење спуштањем на предмет за седење', а седети - значи вршити извесну радњу.

Прво питање на која ваља одговорити - јесте питање 'видског система'. О томе Белић, како видимо, износи два опречна става. Вид посматран у целини чини систем значењских и структурних корелација. Посмтран парцијално, у области лексичког система, он је 'несистематизован' Ми бисмо радије рекли да није до краја систематизован. А поред тога лексичке видске корелација, прво, нешто су друкчије него оне међу префиксираним глаголима; и друго: не тичу се ограничења радње, већ њеног схватања као целовитог догађаја.

3.5. У области префиксације, вид српскога језика је далеко потпунинје и доследније систематизован. Белић (2000: 417) мало је затечен том чињеницом, јер мисли да је префикасација, као и суфиксација, секундарног порекла и да je, као средство видске систематизације код глагола, настало управо по угледу на лексичку:

Истина је да перфектизирани глаголи (дакле, глаголи који помоћу префикса од трајних постану перфективни) не постају непосредно тренутни, већ значе један извршени тренутак или извршени део радње на почетку или на крају вршења глаголске радње; али они су увек перфективни и њихово се значење може развити у тренутно (преко резултативног значења или којег другог). Само је тренутно зачење (исп. мрети : умрети, чинити : учинити - где је умрети, учинити тренутно, иако су то перфектизирани глаголи) код њих увек секундарно, добивено посредним путем.

Исто тако када се, полазећи било од трајних глагола било од тренутних, изменом основе граде изведени глаголи, добивамо две врсте итератизираних глагола:а) трајноучестале (ходити : ходати) и тренутноучестале (пасти : падати, сести : седати и сл.). 
Белић чак и не помиње могућност употребе изведених непрефиксираних глагола као дуративних (исп. горе поменуто: „погледајте како лист пада“, за разлику од: „лишће пада у касну јесен“, „зрела крушка сама пада“ или сл.).

Ако има аргумената за одлучивање о примарности постања видских корелација у словенским језицијма, онда се они не могу тражити у сфери лексике, јер тамо, прво, видске корелације нису довољно чврсте; и друго: оне су друкчије по типу. Настале су просто аспекатском престилизацијом и видском транспозицијом факултетивних у обвезатне корелацијске односе. По свему судећи, ради се о секундарној појави, насталој тек кад је префиксацијски видски систем већ био довољно учвршћен, прецизиран и урећен.

3.6.Иван унутрашњих односа постоји један, и то одлучујући - историјски аргумент; њега је открио сам Белић, и формулисао у раду о 'словенском инјунктиву'. Белић (2000: 443) на свој начин износи тај проблем, и то у вези са значењем глаголских времена, тј. односом тзв. 'инјунктива', обавезно праћеног 'аугментом', каснијим префиксом, и нпр. презента, лишеног 'аугмента'. Значење прошлости код инјунктива по Белићу, у балтијскословенској епоси, прелази узначење свршености префиксиранога глагола, у односу несвршеност простога:

Инјунктивни облик * próbheret према облику садашњег времена *bhéreti, употребељеном у синтаксичком релативу..., значио је радњу свршену према радњи несвршеној, јер су у синтаксичком релативу времена добијала значење вида. Како је, поред употребе префикса, разлика међу тим облицима у употреби у инјунктивном облику претериталних личних наставака према презентским у облику *bhéreti, то се у балтиско-словенској епоси, по моме мишљењу, однос извршене и просте глаголске радње према свршеној и сложеној и схватио првобитно као однос у једној примарних наставака према секундарним наставцима у другој. На овом принципу настало је у балтиско-словенском заједничком језику преуређење целе системе наставака код ових глагола: перфективни глаголски облик претстављао је имперфективну глаголску основу сложену са префиксима према имперфективном глаголском облику од имперфективне просте основе и презентских личних наставака. 
Нема сумње, значење перфективности, према имперфективности, настало је у вези са настанком префикса и префиксираних глагола, у односу на беспрефиксне, и то у време када просте глаголске основе још нису почеле са учвршћивањем видских корелација. Ове потоње формиране су под утицајем првих, али видска прерасподела код простих глаголских основа није доследна, а није ни по истим критеријима извршена као код префиксираних. По свему судећи, та је поткатегорија заправо секундарна у односу на префиксиране основе. По ономе што каже Белић, а и по неодређености видских значења код изведених глагола (учесталост поред просте трајности), слободно је закључити да су суфиксацијске корелације у ствари настале касније, као терцијарна појава.

4. Све у свему, видска значења код глагола резличитог су постања и различита су по природи својој. Видски систем словенскога глагола, услед свега тога, није никада достигао високу хомогеност, какав је нпр. систем морфолошких, нпр. временских корелација код глаголских речи, или падежних, код речи са деклинацијом. О томе и Белић (2000: 459) исправно, иако недовољно јасно суди:

Словенски глаголски вид - претствља целу систему, која само на први поглед изгледа да је саграђена изједна и да има потпуно унутрашње јединство. У ствари, она није таква. Само је најопштија црта те системе заједничка - перфективност и имперфективност; иначе оно што се под том општом карактеристиком крије - није једнако. Неједнакост долази отуда што се по неопходности у једној системи нашло оно што има заједничке најопштије црте, - иначе и по пореклу и по специфичком значењу може бити различно. На пр. однос сести и седети претставља прави однос моментане, извршене радње, тј. саме извршености једне радње, и њена трајања. Перфективност сложених глагола није таква. Она, као што сам већ истицао, претставља ограничење глаголске радње глаголским префиксом. Према томе, иако су глаголи обеју врста перфективни, њихова је перфективност различна. То исто вреди за однос итертаивних глагола према трајним. У глагола сести : седати - значење седати састављено је из неограниченог понављања значења глагола сести; то је свакако нешто друго неголи трајно значење глагола седети... На тај 
начин, глаголски вид словенски обухвата глаголе који су на различне начине дошли до општег видског значења. Због тога има међу њима и стварне разлике.

Према томе, споља посматран, словенски глаголски вид је систематска и конзистентна категорија. Али подробнијим и прецизнијим увидом у унутрашње корелације, откривамо разноврсне неуједначености у том систему, које се огледају у употреби вида, а које су последица разноврсности постанка појединих поткатегорија.

5. Општи закључак расправе коју смо водили у овом раду води следећем.

5.1. Словенски глаголски вид у односу на слична значења несловенских језика представља системску појаву обавезних дистинкцијских параметара по којима се издвајају свршени и несвршени вид; несловенски језици несистемски су у односу на те дистинкције.

a) У словенским језицима видске дистинкције везане су за лексичку, одн. лексичко-творбену основу, и не испољава се на граматичком или синтаксичком плану. У несловенским језицима одговарајуће вредности углавном су употребне по статусу, и огледају се на синтаксичком плану.

б) Словенски глаголски вид је лексикализована појава која се испољава у виду обавезних дистинктивних обележја, док је у несловенским језицима одговарајућа дистинкцијска мрежа практично факултативна.

5.2. Српски, а вероватно и словенски видски системи у целини - нису заправо јединствени. Делом су засновани на чврстим системским корелацијама неосетљивим на контекст итд. Делом су, међутим, несистематични, и испољиви у дистинкцијама које су мање или више факултативне, зависне од врсте значења и контекста у којем се глаголска реч нађе.

a) Ако хијерархичност видских категорија схватимо с обзиром на разлику Словенског вида и еспекатских вредности несловенских језика, онда смо у ствари обавезни и у српском језику разликовати те две категорије. Прво је словенски вид са прецизно израженим односом имперфективности, дакле значења неограниченог процеса, према перфективности, тј. 
истицања границе прецеса - почетне или завршне - што се огледа код глагола сложених са префиксима. Друга је значење глобалности радње, обухваћене почетном и завршном границом, без истицања дужине трајања процеса, према одсуству глобализацијског смисла. Ову ваља назвати истим именом како је именована у несловенским језицима - глаголски аспект.

б) Категоријална хијерархија у вези је са генетском: најсистематичнији склоп дистинкција код префиксираних глагола према беспрефикснима, у односу на лексичке дистинкције код простих глаголских речи - упућује на генетску хијерархију: најпре је по свему судећи дистинкцијски видски комплекс настао у вези са појавом префикса; а видске дистинкције код сложених глаголских речи повратно су и накнадно деловале и на просте глаголе, увлачећи их накнадно у систем, али сразмерно непотпуно и несистематично.

в) Изведени глаголи познају такође дистинкције сличне виду - перфективност/ имперфективност неизведених према фреквентативности изведених - али то је терцијарна појава, за коју на располагању стоји термин који одговара немачком Aktionsart или р. 'способы глагольного действия'.

\section{2. Глаголски вид и временски облици}

1. Белићеви ставови о глаголском виду и времену заслужују посебну пажњу. Белић је творац теорије о 'индикативу' и 'релативу'. У својим раним радовима он инсистира на идеји о тесној вези између видских и временских значења, а у каснијим својим истраживањима дистанцира се од тих налаза. Полазиште за своја разматрања Белић је очито нашао у трактатима о класичним језицима, и у категоријама индикатива, конјунктива итд., који се разликују и на обличком плану, док у словенским језицима такве дистинкције нису обележиве морфолошки, већ свој израз - по Белићеву мишљењу одговарајуће семантичке категорије налазе у синтаксичким дистинкцијама. Он при томе подразумева да српски 'индикатив' стоји према класичном индикативу, док 'релатив' сажима остале временске категоријалне појаве, распоређене 
на специфичан начин (касније поред 'релатива' Белић у расправу уводи и 'модус').

1.1. У раду 'О синтаксичком индикативу и 'релативу' (Белић 2000: 295) он најпре дефинише основне категорије употребе глаголских времена, а затим их доводи у везу са видом, и износи схватање о видским односима у вези с тим категоријама. У 'индикативу' се испољавају временски односи означени датим обликом, а у 'релативу' се та значења губе и уместо њих облик означава једино одговарајући вид. О томе нпр. стоји - као закључак разматрања грађе - следеће:

Према овоме види се јасно да сва времена која сам поменуо [презент, аорист, перфекат, футур] пренесена из индикатива у 'историску' прошлост или у 'релатив', или пренесена из категорије која означује 'ефективну' радњу одмерену према садашњости у категорију која значи ону прошлост која не стоји ни у каквом односу према садашњости и према њој се не одмерава, дакле, која значи прошлост према ма коме моменту саопштавања - губе своје право временско значење и остају само са својим значењем вида и обележавањем код на пр. перфективног презента, аориста и футура момента у прошлости када се радња извршила. Према том се види да српскохрватски језик има нешто сасвим супротно морфолошком слагању времена у другим језицима: временска ситуација 'релатива' нивелише различна времена која се у њој употребљавају и даје им свима свој временски карактер. Тако је дошло да се таква прошлост може исказати и презентом, претериталним временима, и футуром. С друге стране, времена се јављају у свом пуном значењу, и ту се једно не може заменити другим, у синтаксичком индикативу, у којем се сва времена одмеравају према једном тренутку садашњости, моменту када се говори. Отуда је јасно да се у индикативу може као презент употребити једино радња која траје, дакле, презент имперфективних глагола, и то ј е индикативни презент нашег језика. Значи, дакле, да можемо у српскохрватском језику имати подједнако 'индикативни' презент и 'историски' или 'релативни' презент, 'индикативни' аорист и 'историски' или 'релативни аорист,' 'индикативни перфекат' и 'историски' или 'релативни' перфекат..., 'индикативни' футур или ‘историски’ или 'релативни’ футур и т. д. 
1.4. Дистинкцијски потенцијал индикатива према релативу - како Белић мисли - огледа се у временским значењима првога, и потчињавању другога контекстуалним условима, при чему на контекст прелазе ингеренције за одређење временских односа у којима се радња реализује; или пак у свођењу временског значења на видско. То смо делимично видели и у цитираном пасажу, а то је још јасније изражено у следећим редовима његовог текста (Белић 2.000: 297-298):

...глаголи у синтаксичком релативу немају свога временског значења, него то значење, без обзира какав морфолошки знак имају, добијају од главне радње према којој се употребљавају или према временској ситуацији у којој се находе...

Релатив се може употребити и онда када се не жели обележити нарочито време у којем се нека радња збива, него када се показује да она вреди за сва времена. У том случају презент, претерит и футур значе исто, јер се свако од тих времена употребљава према замишљеној прилици и значи само оно што такво време, било према своме глаголском виду, било према нианси вида која се садржи у времену пренесеном у синтаксички релатив, - може значити.

Ово је централни моменат Белићеве почетне теорије. Питање релатива он једнозначно своди на обезвремењавање:у неадекватним ситуацијама глаголски облици губе временски смисао и постају једино носиоци видских дистинкција.

1.5. Један од доказа за свођење временског значења на видско - јесте, по Белићеву мишљењу, - и могућност замене једнога временског облика другим, при чему се чува видско значење глаголске основе, а време бива неутралисано (Белић 2000: 298):

Много је сложенија ствар када је прирок какав лични глаголски облик. Јер тај лични глаголски облик има, у исто време, и морфолошки знак за обележавање глаголског времена. Међутим он се употребљава у овом случају у реченици у којој се не жели да обележи време глаголске радње, него се сматра да је глаголска радња применљива и за садашњост, и прошлост, и будућност. 
У реченици 'Два лоша избише Милоша' - 'избише' нема значење аориста, него поузданости да ће се радња извршити... Довољно је, дакле, да се 'избише' не употребљава овде у синтаксичком индикативу... Зато би се у оваквој реченици овакав аорист могао заменити и презентом или футуром: 'Два лоша избију Милоша', 'Два ће лоша избити Милоша' и сл. У свима овим случајевима губи се време, јер се оно не обележава према једном моменту садашњости, и глаголска се радња своди на обележавање могућности извршења глаголске радње. Одавде излази да 'независни релатив' (исп. независни коњунктив или оптатив у другим језицима и слично), када се обележава личним глаголским обликом, добија лаку ниансу модалног значења. Она долази отуда што се радња приписује свима временима, па се према томе она може увек вршити. Чим се 'два ће лоша избити Милоша' може односити на прошлост, онда ова будућност у прошлости значи само поузданост извршења глаголске радње, а не неку стварну будућност.

У пословици 'Зрела крушка сама пада'... овај презент нема презентско значење, јер није употребљен у синтаксичком индикативу, већ значи само оно што претставља глаголска основа с обзиром на глаголски вид. У првом случају имали бисмо једну безвременску реченицу: 'Свака зрела крушка сама пада', где ово 'пада’ значи особину, која је стална...

Врло је тешко сагледати домет Белићеве аргумантације. Ако се 'Два лоша избише Милоша' - без промене временске перспективе - може заменити са 'Два лоша избију Милоша' или 'Два лоша избиће Милоша', онда с пуно разлога можемо сва три облика - и аорист и презент и футур - сматрати атемпоралним (вид није овде од важности јер заправо припада семантици глаголскеоснове). Но прецизнији увид у односе сугерира закључак да међу облицима ни у овом случају, као ни иначе, нема апсолутне еквиваленције. Аорист 'избише' није временски неутралан, већ има проспективни смисао са нијансом очекивања догађаја по завршеном акту говорења, али у самој ситуацији говорења. Футур 'избиће' своју проспективност такође комбинује са нијансом очекивања, али без временског ограничења постпрезентног значења. Презент 'избију' неутралан је у односу на оба поменута момента, с тим што подразумева неограниченост 
садашње ситуације, омнипрезентност догађаја у најширем смислу речи.

1.6. У другим приликама Белић износи нешто друкчији став.

a) Тако у расправи 'О употреби времена у српскохрватском језику (поводом расправе о томе г. А. Мусића)' (Белић 2000: 305), - апострофирајући Мусића - он се изјашњава на следећи начин:

У приповедању, које претставља радње које припадају у потпуности прошлости, радње које се не одмеравају према садашњости и које немају никакве везе са садашњошћу, презент имперфективних глагола значи радњу која траје у прошлости, а презент перфективних глагола - радњу свршену у прошлости. Они значе оно што значи њихов глаголски вид.

Формулације које смо управо цитирали воде закључку о комбиновању вида и времена, а не о искључиво видском значењу. Мисао да презент и аорист 'за прошлост' 'значе оно што значи глаголски вид' није у себи конзистентна, јер ако је облик употребљен 'за прошлост', он ипак не губи сваку везу са временом говорења? Али даље: презент није способан да сам 'означи прошлост', па је и то заправо грешка у формулацији. Но битније је да тиме на светло дана излази загонетка о употреби презента за прошлост - откуда таква могућност, и у каквој је она вези са природом презента као облика за актуелну садашњост?

б) Објашњењем временски неограничене репетитивности (Белић 2.000: 307) додирнуто је једно врло осетљиво питање из горе назначеног комплекса: о улози адвербијалних одредаба у констелацији временских односа, и односу њиховом према основном временском значењу облика:

Исп. на пр. „Ћера коња ка Удбињи граду, кога ћаше на путу сретати, сатисне га с пута испод пута“. Овде је заиста перфективни презент употребљен у итеративној реченици или у итеративној вези; али он сам нити има овде нити игде другде итеративно значење. Овде он значи „када кога среташе на путу, он га потисне с пута“, према томе 'сатисне' или 'потисне' 
има значење свршене једне радње... Он значи само 'тренутну' радњу; што се та тренутна радња 'сваки пут' дешава, ту итеративност показује израз 'сваки пут'...

Репетитивност, тј. поновљивост догађаја, коју Белић изједначује са итеративношћу, по њему је ствар (овде подразумеване?) адвербијалне одредбе, а не глаголског облика, који бива значењски апсолутно неутралисан?

в) Пажњу у овом контексту заслужује и следећа Белићева интерпретација о 'индикативу' и 'релативу' (Белић 2000: 309):

У разговору (у смислу синтаксичког индикатива) аорист значи радњу која се извршила непосредно пред моментом сопштавања (отуда долази код г. Мусића спомињање радње која је управо сада прошла), а у приповедању (у смислу синтаксичкога релатива), - радњу која је тада. т. ј. онда била када се извесни момемат у прошлости одређује. Према томе, ако испоредимо ово двоје, онда је јасно да у синтаксичком индикативу (у стварном разговору) аорист има значење стварног времена, и то одређеног времена, ограниченог на моменат непосредно пред моментом саопштавања, а у синтаксичком релативу (у стварном приповедању) - своди се на значење вида: он значи извршени моменат једне имперфективне или перфективне радње у прошлости који се десио пре или после или у време вршења друге радње. Обично је тај моменат завршни, али он може бити и почетни (то зависи од глагола, исп. он запева тужну песму па заћута (у оба случаја значи почетни завршени моменат перфективне радње)). Као што се види, чисто временско значење или, боље да речем, одређено временско значење овде се губи: место да значи непосредно извршену радњу пред садашњошћу - он значи извршени, обично завршни, моменат глаголске радње у прошлости.

Тврдња о свођењу временског значења на 'видско' код Белића се овде по ко зна који пут подвлачи и подупире аргументима. Нпр. у стиховима: „Ја кад био под бијели Жабљак, виђе Иван своје б’јеле дворе: бијели се у висину кула, на ћошета сићани чардаци, а сјају му срчали пенџери“аорист 'виђе' нема временско, већ само видско перфективно 
значење? Време би у том случају било у надлежности временске клаузе 'кад био под бијели Жабљак'. Аорист 'виђе' стварно је заменљив презентом 'види', што би сугерирало да је његово значење „одређеног времена, ограниченог на моменат непосредно пред моментом саопштавања" потпуно анулирано. Но постоје два момента који нам - ако останемо при Белићевим схватањима - сметају у таквом закључивању. Први је теоријски, а други практичан. Наиме, реченица 'кад био под бијели Жабљак' у предикату има крњи перфекат, па с обзиром да је то 'релативски' облик, и да се према томе и он своди на 'значење вида', и он би по томе био онеспособљен да означи прошлост, која је овде евидентан факат. Практични моменат тиче се самог значења прошлости, које је несумњива оријентациона чињеница.

Стожерну улогу овде има управо темпорална клауза са везником 'кад', чиме је отворена временска ситуација ка којој конвергирају временски облици. Крњи перфекат '(кад) било, без обзира на релативни карактер, није заменљив презентом '(кад) буде' или сл. Најбоља његова замена јесте имперфекат '(кад) бјеше', уз напомену да би крњи облик морао значити претхођење ситуацији коју означава имперфекат. Изгледа заправо да овде недостаје помоћни глагол из чисто техничких разлога: ради стиха, и ради онога 'ја' на почетку. Без њега би стих гласио заправо 'Кад је био..., а сведочанство о томе јесте и само значење прошлости, јер се ова поклапа са описаном ситуацијом о којој је реч ('кад био под бијели Жабљак' односи се на време 'бивања под Жабљаком', а не на оно које томе претходи) и као прошла одмерава с према времену говорења, само с том разликом што имперфекат наглашава 'актуелност' (по старијим схватањима 'доживљеност’ прошлости, док перфекат има у том правцу неутрални смисао. Аорист, са своје стране, означава „извршени... моменат глаголске радње у прошлости“, и то је овде истина. Оним 'у прошлости' Белић дезавуише самог себе у тврдњи о свођењу на чисто значење вида.

Да је дефиниција по којој аорист „значи непосредно извршену радњу пред садашњошћу“ гласила да аорист „значи радњу вршену или извршену у садашњости пре момента говора“ - онда би Белић са лакоћом извео закључак 
да аорист за прошлост у ствари има значење Мусићеве 'замишљене садашљости', тј. садашњости схваћене у општем смислу широке ситуације у коју пада време говорење, а и догађања о којима је реч. Збивања у наведеним стиховима: „Ја кад био под бијели Жабљак, виђе Иван своје б’јеле дворе...“ - представљена су из две временске перспективе. Префект '...[кад] је био' значи прошлост у односу на време говорења, и као предикат временске реченице обележава ситуацију збивања као прошлу, чиме даје прошли карактер и осталим дешавањима у оквиру те слике.. Аорист 'виђе' својим значењем претхођења акту говорења и везаности за садашњу ситуацију - даје целој ситуацији значењску нијансу широке садашње ситуације, боље рећи оног њеног сектора (по J. Вуковићу 'одсека') који претходи самом акту гворења (она се може означити, рекосмо, као актуелна прошлост). Презенти 'бијели се', 'сјају' износе догађаје обухваћене том ситуацијом без даље спецификације временских односа.

Временске перспективе у којима се приказује догађај, по ономе што смо горе утврдили, стално се укрштају и чине мрежу односа у којима се као на неким координатама, оцртавају глаголски садржаји. 'Релативна' употреба аориста, према томе, стварно значи измену односа у којима се дешава оно што значи, али не и свођење на значење вида, тј. не на потпуну неутрализацију временског значења. Релативно пак употребљен презент има 'временско локализациону' функцију, упућујући на везаност догађаја за друкчије обележену или уоквирену ситуацију. Релативна употреба, како видимо, обележава мало преиначено, 'транспоновано' значење које облици имају у индикативу. Овим не тврдимо да неутрализација временског значења не постоји као лингвистичка чињеница, већ једино да у релативној употреби глаголских времена није увек на делу.

2. М. Стевановић (1991) врло интензивно се бавио глаголима уопште, па и глаголским видом и временом, покушавајући да сажме обимну литературу о тим питањима (наведену на стр. 530), и да се сам изјасни о проблемима.

2.1. У општем ставу он прихвата 'пунктуалну' теорију вида: 
Несвршени (имперфективни) глаголи означавају радњу неограниченог трајања, а свршени глаголи - означавају један свршени тренутак радње, али не увек само то. У значењу неких свршених глагола подразумева се и вршење радње које је претходило томе тренутку...: прочитати, прежалити, превести. Глагол 'превести књигу', рецимо с једног језика на други, или превести некога или нешто преко широке реке. тј. вршити и извршити превођење с једног језика на други, или превођење нечега преко реке, - поред извршености тих радњи, које је битно, укључују у своје значење и ток вршења дотичних радњи пре њихова извршења. Ипак је главно, или, како рекосмо, битно означавање свршеног тренутка, који је у три сад наведена и у многим сличним примерима завршни тренутак процеса радње (Стевановић 1991: 534).

Анализа није сасвим погођена, и то је врло битна ствар за разумевање ових примера, а и вида у целини. Наиме 'превести' (те: 'преписати', 'премостити', 'префарбати', 'претворити' и др.) - не значи радњу ограничену само моментом завршетка, већ заправо и почетка. Префикс 'пре-' не инсистира посебно ни на почетку ни на завршетку процеса, већ глагол једноставно означава радњу као целину, не допуштајући ближи увид у само трајање. Увид је могућ само ако га пратимо у употреби: 'превести с енглеског' примарно означава полазни моменат, док 'превести на српски' - завршни; 'превести са енглеског на српски' - оба. Видљивији је, али из другог угла, исти смисао и код простих перфективних глагола као 'пасти', 'сести', ‘лећи', 'дићи' итд. (за разлику од 'пустити', 'маћи', 'стати', 'рећи', 'пући', 'црћи' и сл.). Нпр. 'пасти с дрвета' у првој инстанци осветљава почетак, 'пасти у воду' - завршни, док 'пасти с дрвета у воду' - опет и један и други. Друкчије је код 'пустити' и сл., где недостаје перспектива почетка и краја, већ су оба момента сведена у једну тачку. Ако признамо постојање тзв. продужносвршених глагола типа 'поразговарати,' ‘пошетати,' ‘покарати' и сл., онда су неки горе поменути, нпр. 'превести' и њему слични, такође продужно свршени, само што је продужност код оних са 'по-' експлицитна, а код оних са 'пре-' имплицитно садржана у значењу глагола. 
Закључак који одавде следи противан је 'пунктуалној' теорији као општем схватању перфективности, јер не само 'тренутак' краја или почетка, него често и цео процес означен глаголом бива сажет у перфективно значење. Једном је то стварно сажетост у једну тачку ('пасти' у 'Пао је и повредио се' - значи у ствари почетак, ток и крај догађаја, док код 'повредити се' нема тога, већ је 'пунктуално' значење једини садржај лексеме), други пак пут перфективни глагол значи стварно почетак или крај радње: 'потрчати' vs. 'дотрчати' или сл.

Крајњи исход расправе своди се на следеће: постоје перфективни глаголи општег значења (углавном сви прости, и известан број перфектизованих). Они „означавају радњу као недељиву целину“ (Бондарко и Булањин 1967: 31), а постоје и они посебног значења, који обухватају 'свршени тренутак', али поред тога и додатна видска значења

2.2. У поглављу о глаголима 'са два вида' Стевановић (1991: 542-543) утврђује да код њих „вид зависи од значења које дотични глагол има у реченици: 'видети' значи чулом вида сазнавати и имати моћ тога сазнавања, што је свакако неограниченог трајања, и тај је глагол у овим значењима несвршеног вида; 'чути', исто тако: чулом слуха сазнавати и имати моћ тога сазнавања. У овим случајевима и тај је глагол несвршеног вида. Међутим, 'видети' и 'чути' значе и: чулом вида, односно чулом слуха сазнати - у једном тренутку, дакле, и тада су ти глаголи свршеног глаголског вида. Из реченичне ситуације је сваки пут лако одредити с којим од ових значења су ови глаголи употребљени, па, дакако, и кога су глаголског вида у одређеној употреби“. Али сем правих двовидских постоје и глаголи „који су у основи и скоро свим њиховим значењима имперфективног вида, а тек у неком посебном значењу и перфективни“ (543-544).

Такав је, рецимо, глагол ‘брисати', који, поред осталог, значи каквим средством уклањати што написано, са значењем у којем се иначе употребљава основни глагол сложен с префиксом из- као 'избрисати' у примерима типа: 'Одлучили су да се брише члан 13’. Затим глагол 'вући’ (употребљен са значењем 'извући'): 'Одем своме продавцу, вучем доњи лоз и не добијем ништа', па 'гађати’ и 'пуцати' (у значењу ‘опалити'): 'Нанишаним и гађам, али не погодим'“ итд. 
Стевановић (544) налази да и „перфективни глаголи, какви су: 'казати', 'казнити', 'малаксати', 'стрељати' и сл. - у контексту каткад, тј. у одређеној језичкој ситуацији, постају имперфективним: ‘Ја вам кажем’ (значи: Ја вам говорим); 'Време носи, а невреме казни' (тј. кажњава); 'Војници 3. чете малаксају' (мисли се малакјсавају); 'И потом ће сваком на смрт осуђеном главу сећи, а само војнике стрељати’.

А што „имперфективни глаголи [у перфекту] имају перфективно значење...: 'Пшеница је већ класала' (тј. избацила клас)...; 'Ја бих се задржао и здравио се с њим' (у значењу поздравио се); 'Школско звоно је звонило у 7 сати' (мисли се огласило је почетак рада); 'Страдао је као Јанко на Косову’ (тј пострадао је)“ - тиме неки доказују „како перфекат на једној страни има карактер свршености, док презент (мисли се прави) зна само за трајање“. - Но ово „није никакав доказ јер ти глаголи и у презенту употребљени могу имати перфективно значење (исп. за ово... Вуков пример: 'Када му карађорђе потом пише да Турке пошаље у Београд, јави му...)““ (Исто м.; даље: 544-545).

Истичући затим да се ови глаголи... не могу сматрати двовидским - ми подсећамо да нам и њихов случај јасно открива на који начин се глаголски облици међусобно разликују по виду у језицима без морфолошког видског система. Иако је несумњиво двовидским глаголима основа имперфективности у презенту, а основице перфективности у претериту, ово никако не треба буквално схватити да су употребљени уобликуперфекта ти глаголи увек перфективни, а употребљени у презенту увек имперфективни. Напротив, несвршени глаголи и у перфекту, по правилу, чувају свој вид јер је он, у српскохрватском као и у другим словенским језицима, најчешће у основи самог глагола, а не у овоме и ономе глаголском облику...

Ипак је несумњиво да је свршеност више у карактеру претериталних времена, а несвршеност у карактеру презента, бар у његовој правој, индикативној употреби...

a) Интересантно је додати две ствари. Прво, да међу двовидским глаголима истакнуто место имају просте речи које 
описују људске физиолошке функције, као 'јести, пити, ручати, чути, видети' и сл., дакле по свој прилици оне из најстаријег лексичког фонда, на једној страни, а на другој нове позајмљенице из језика који не познају вид: 'фарбати, карминисати, телефонирати, толерисати, глеђосати, оварисати’ итд. То показује, на једном крају лествице, да глаголски вид из неких разлога није до краја изграђен, као на другом - да његова снага у најновије доба постепено јењава, и да је код деривацијских форми боље изграђена него код простих. Ово је - невероватно али истинито - у вези са горе учињеном напоменом да је словенски глаголски вид озгледа примарно и настао у префикасалних сложеница, па се проширио и на просте речи. Са истога овог гледишта ваља судити и о глаголским облицима: једни су видски даље развијени од других. Или је можда боље устврдити да су једни сачували прастаро стање које подсећа на језике са дистинкцијама контекстно јако условљеним, док су други видски одређенији.

б) Друго што ваља поменути јесте да у свим овде поменутим случајевима видска значења код простих глагола (и неких форми са префиксом) немају 'пунктуални' карактер, као у секундарних глагола: прости глаголи „означавају радњу као недељиву целину“. Све то показује да, и по пореклу и по основној природи, - словенски глагол није јединствен: (а) код простих глагола има 'комплетивну', а код префигираних 'пунктуалну' природу; (б) код простих (и изведених?) глаголских речи он је у основи факултативан, а код префигираних обвезатна особеност.

3. М. Ивић $(1977,11)$ цитира Комријеве речи (Комри 1976) по којима постоји потреба на нивоу дубинске структуре језика увести дистинктивно семантичко обележје 'комплетивности'. До истог би закључка ауторка дошла да је прегледала словенску литературу (В. горе опаску да перфективни глаголи „означавају радњу као недељиву целину“: Бондарко и Булањин 1967: 31). „Ако би се то прихватило - коментар је М. И. - обележје 'комплетивно' (+) добили би словенски глаголи перфективног, а обележје (-) глаголи имперфективног вида“. Ваља овоме насупрот додати да је 'комплетивност’ (+/-) обележје само примарног видског значења, али 
не и секундарног, које познају 'перфектизовани' глаголи (Посебну пажњу у овом правцу, и посебно истраживање, заслужују 'имперфектизовани' изведени глаголи).

4. Пол Луј Тома (2007: 54) у свом настојању да нађе 'видске инваријанте' помиње више видсих опозиција, као нпр. 'глобални(свршени)'-'несвршени (/'парцијални'?') и 'довршени (свршени)'/'недовршени (несвршени)'. Критички се осврће на став Ирене Грицкат о двовидности глагола 'питати', поводом факта да је у реченици 'Питао сам га, али нисам добио одговаор' он перфективан, - али не даје одговор какав је заправо.

a) Даље Тома истиче једну особеност перфективних глагола коју Белић у својим истраживањима није приметио, нити његова пунктуална теорија допушта де је примети, а то је нпр. да перфективни глаголи нису увек носиоци тренутности и на семантичком плану. Малициозну напомену Ђ. Грубора: „Дићи се измучио док је, за сат, дигао сидро са дна мора, а Белић му признаје само тренутак“- Тома поткрепљује даљим примерима типа: 'Принцеза је преспавала сто година у дворцу усред шуме', додајући овоме и обратне примере тренутног значења имперфективних глагола: 'Гледао ју је само једну секунду'. Но Тома је, са своје стране, дезавуисан у целини још теоријским схватањима Хермана Паула, која смо изложили горе. Паул је утврдио да је могућа перфективна примена лексички имперфетивних, и имперфективна перфективних глагола.

Критика Белићевог схватања о опозицији 'тренутни'/'трајни' глаголи, како ју је Тома спровео, заправо је неупутна, јер не води рачуна о системском стању речи у односу на контекстну варијацију, и чак могућност неутрализације системских опозиција под притиском контекста.

б) Тома и сам у својим интерпртацијама запада у тешкоће из којих није успео изаћи. Али један његов закључак прелиминарно учињен (Тома 2007: 57) заслужује сваку пажњу. А то је следећи: „Перфектив јасно означава да је радња узета у обзир у својој целости, што ће бити његово облежје у односу на имперфектив, који о овоме не каже ништа“. То је иста она идеја која је садржана у дефиницији руских аспектолога, по 
којима је 'целовитост радње' управо одлика значења пефективности. Можда би - да будемо до краја благонаклони према Томаовим истраживачким напорима - његов термин 'глобалност' више одговарао него 'целовитост', јер инсистира заправо на 'аспекту', који ми желимо схватити као 'ракурс' - мерен удаљеношћу тачке посматрања од самог објекта. Наиме посматрана из удаљеније перспективе - и радња, исто као и предмет - бива лишена конкретних детаља и указује се у општим обрисима, а подробности њеног тока остају непримећене.

\section{3. Вид и значење временских облика у новијој интерпретацији}

1. Дуго је у науци о значењу глаголских облика вођена расправа о томе да ли је глаголско време самостална категорија или је зависна од вида. Видели смо какво је Белићево схватање о томе: он мисли да временски облици своје значење чувају само у индикативно употреби, док га у релативу губе или своде на видско значење. Пошто се та расправа сматра завршеном, остаје нам да утврдимо да је од својих полазних помиција одустао и сам Белић. Зато ћемо овде упутити на његова новија схватања. Он у контексту завршних лингвистичких испитивања тврди „да су глаголски вид и глаголско време две различне ствари иако се извесно видско значење може доботи на основу употребе извесног глаголског значења у извесном времену..., исто онако као што се глаголи извесног видског значења могу употребити у једним временима, а у другима не могу, или као што се неки видски облик могао употребити за извесно временско значење када су им се временски облици, у извесној употреби, по значењу знатно приближили“ (Белић 1998: 223). Развијајући своје мисли даље, Белић (1998: 229) прецизније формулише неке додатне моменте које сматра битним за разумевање односа вида и времена:

Ја мислим да ту треба разликовати три потпуно различна случаја: 1) када се глаголи извесног видског значења које 
чини део њихове основе употребљавају у неком времену које допушта да се њихово значење може комбиновати са временским значењем дане категорије (каква је напр. искључива употреба трајних глагола у [индикативном] презенту...); 2) када се значење вида добија помоћу временског значења и 3) када се облик вида употребљава за временско значење (исп. случајеве код футура). Ја мислим да други случај претстављају индоевропски перфекат и индоевропски аорист. Кад се индиско bududhé тумачи као 'он је дошао до свести', тј. 'он је будан', грчко тв́лvбто 'er hat etwas in sein Bewustsein eingehen lassen, hat erfahren, weiss' и сл., ...имамо посла са радњом у прошлости која је резултативна зато што својим извршењем, дакле прошлошћу, добија као резултат ново значење стања. Чим аорист значи моментаност ('Punktualisierung') радње, без икакве претставе о њену трајању..., онда је јасно да се то могло добити једино слагањем претериталности са тренутношћу глаголске радње...

Тачне Белићеве констатације праћене су не сасвим тачним интерпретацијама. Наиме, није реч о укрштању вида и времена већ о појавама у семантици неких претериталних, а и других облика који у великој мери подсећају на словенски вид. Али ми ћемо поставити тезу да се, у ствари, не ради о категорији вида у правом смислу, већ о појавама блиским виду. Размотрићемо с тим у вези следећу расправу коју J. Вуковић води са П. Ивићем.

2. Вуковић каже да је „П: Ивић сасвим лепо осетио радњу исказану имперфектом као процес, сам процес - у ствари, и како одатле треба полазити да би се његова радња најлакше могла специфицирати“ (Вуковић 1967: 290).

Међутим, и Ивић нас мора довести у забуну кад на другом месту, говорећи о диференцијалним моментима претериталних глаголских облика, каже: 'Стога није погрешно рећи да је простим претериталним временима радња захваћена као збивање догађаја, процес (ако под тим подразумевамо нешто што је везано за одређено време и околности у њему), а у перфекту као го факат, податак (JФ XX, стр. 258). А пре тога, кад је реч о једној разлици употребе аориста и имперфекта (уз прилог доста), читамо: 'У таквим примерима имперфект не 
може доћи због тога што он значи паралелизам са ситуацијом у прошлости, ситуацијом које више нема (тада). Уосталом, овде је битно да се не мисли на време трајања радње, на њену слику, него на чисту радњу као такву, на њено вршење или невршење. У питању је радња као факат, мишљење говорног лица о томе факту' (стр. 256). Не можемо никако, ни под условом да вежемо аористну радњу за околности, ову радњу схватити као процес, нити се ту могу наћи икакви диференцијални моменти између аориста и перфекта. То је једно. А друго је, радња као факат слаже се за идентификовање перфекта, али колико она одговара аористу, не може се то разумети из оваквог начина формулисања мисли, које иначе могу бити ма како добро формулисане“.

И поред контроверзе у Ивићевим објашњењима - на једној страни код аориста се „не мисли на време трајања радње, на њену слику“, а на другој се аорист сматра обликом који значи догађаје у одређено време (у 'доживљеној прошлости') - Ивићу се ипак не може оспорити тачност тврдње да аорист несвршених глагола по правилу упућује на 'радњу као факат', дакле 'комплетан догађај. Сама ова контроверза представља теоријску загонетку коју би ваљало анализом грађе некако разрешити, али она не смета да прихватимо мисао о 'комплетизацијском' или 'гоализацијском' смислу аориста као тачну. У сваком случају, неспојивост 'комплетивности' и тзв. 'доживљености радње' у значењу аориста коју заправо брани Вуковић - ипак је дезавуисана стварним значењем овог облика.

3. Пратићемо сада Стевановићеву расправу, коме је такође стварно стало до одбране 'доживљености', тј. актуелности догађаја у одређеном временском моменту, временској ситуацији или размаку. Критикујући мишљења својих претходника у испитивању овог облика (Стевановић 1991: 635), он каже:

Стојановићево мишљење, - према коме и аорист несвршених глагола означава само тренутак свршетка радње искључује се... видом тих глагола, који значи трајање њима исказане радње у сваком облику, па и у аористу... Ни ово схватање значења аориста имперфективних глагола, дакле, не може [ce] прихватити зато што се у њему инсистира на свршености радње, коју ипак 
не можемо негирати у извесним случајевима, али која, колико ни извршеност, није битна за ово глаголско време несвршених глагола. Нарочито треба нагласити да, када би се значење аориста несвршених глагола сводило на извршеност, по Мусићу, или на свршеност, по Стојановићу, то би значило да се то значење овога глаголског времена своди на значење вида, што иначе не мисле ни Мусић ни Стојановић.

Аорист по Стевановићу (1991: 631) „означава радње које су се вршиле или извршиле у прошлости, пре тренутка говора“. После дуже расправе у којој наводи ранија мишљења, о имперфективном аористу Стевановић (633639) на крају закључује: „Функције аориста несвршених глагола... не претпостављају никакво истицање прекида, иако можда изгледа да се без тога овај аорист подудара са значењем имперфекта, како је то мислио и изрично тврдио Т. Маретић...“

Међутим, и ако претппоставимо да се аористом несвршених глагола означава вршење радње у прошлости, што је свакако основно његово значење, то не значи да се та два времена подударају својим значењима, иако је у функцији имперфекта као глаголског времена баш то најзначајније... Аористом несвршених глагола се означава вршење радње за једно одређено време у прошлости (635) (нпр.: - Аргатовах три године дана, / и ја вукох дрвље и камење; - Капетан баци уже момцима, који се чудише његову послу).

„...радња у аористу имперфективних глагола, већ по томе што су несвршени, не може значити извршење радње, мада се њим неки пут означава радња која се цела извршила: 'Аргатовах три године дана'... не значи да је онај коме се аргатовање приписује ту радњу извршио до краја, него само да ју је вршио једно одређено време (овде је, штавише, означено и колико - не, наравно, самим глаголским обликом, већ временском одредбом 'три године дана'). Тако исто ни у примеру: ‘...они се чудише његову послу... не може бити ни говора о потпуној извршености дотичне радње, односно завршености стања које се казује односним 
глаголским обликом, него се само констатује да су они којима се ово приписује једно време у одређеној прошлости били у стању које се означава аористом 'чудише се“" (634635). Међутим, Стевановићева дефиниција о 'радњи' која се вршила, или 'стање' „које се означава аористом“ у 'одређеној прошлости' - без инсистирања на 'завршености' - означава и имперфекат, те би се овим потрла граница између ова два облика, и ми бисмо се нашли на Маретићевим позицијама!? Тиме загонетка о којој горе говорасмо није решена, него је постала акутна...

4. Значајни проблеми које пред истраживаче поставља однос глаголског вида и времена могли би се после читања прегледаних радова описати на следећи начин.

a) Временска оријентација глаголских личних облика у начелу је независна од глаголског вида (вид је „унутрашње време“ глаголских речи - А. Белић).

б) Али ипак су неки облици 'селективни'7 у односу на видска значења глагола (имперфекат је нпр. комбинабилан само са имперфективним глаголским основама, док аорист претежно 'бира' перфективни вид). Горе је већ скренута пажња на тај моменат, који у нашој науци није остао незапажен, али је остао нерешен. Бацићемо стога још један поглед на ова питања у целини.

в) Главни проблем отвара се са склоношћу аориста да за комбиновање са имперфективним глаголима постави услов њихове 'перфектизације'. Али видећемо да овај облик није једини који се тако понаша, и да се не ради о 'перфектизацији' уопште, нити само о аористу, иако у првом реду о њему.

в1) Перфектизацији су пре свега склони двовидски глаголи: - „Е побратиме, сад да се дарујемо, ја ћу теби даровати снагу и благо, а ти мене за оба ова дара само своју душу“. Ови човјек премда је био опак, опет помисли хоће ли дати своју душу, али га страх нагна, те се gароваше Вук Прип 139. - И сви људи... крстишие се крштењем Јовановијем Нови завјет 125.

в2) Али рекли смо већ да таквом поступку подлежу и imperectiva tantum: - Чоек... оде дома и покаја се и као прави

7 О 'селективности’ и другим проблемима које отвара тема о аористу и сл., В. Станојевић 2012, Арсенијевић 2013, Станојевић 2014. 
Хришћанин до дубоке старости живлье Вук Прип 140. - И људи видећи чуguше се и хвалище Бога, који је дао власт такву људима Нови завјет 32.

(1) Први пример садржи вањско ограничење глаголске радње у виду адвербијала 'до дубоке своје старости', те се тај моменат може узети за критериј 'перфектизације'.

(2) Други случај не садржи такво ограничење, али ипак 'чудише се' и 'хвалише' не упућују на временски отворене случајеве, већ је на својеврстан начин обухватају као целину. Танасићева мисао да се радње аориста „сагледавају у целини свога постојања“ (Танасић 2005: 424 и д.) мислимо да је добро формулисана као дефиниција овога случаја.

в3) Но има једна ствар на коју је већ Стевановић скренуо пажњу, а која на целу појаву баца ново светло, што се овде може само поменути, а не и разрешити. То је факат да и у другим случајевима постоји могућност 'перфектизације' глагола, одн. да се радње „сагледавају у целини свога постојања“.

(1) У првом нашем случају, наиме, поред аориста 'дарива' садржана су још два облика истог глагола „да се gарујемо, ја ћу теби gаровайи снагу и благо“. Оба означавају једнократни поступак чије трајање није обележено нити је видно као саствани елеменат семантике облика. Радње се и овде „сагледавају у целини свога постојања“.

(2) Погледаћемо и следеће примере:

- Кад већ виgе, да друкчије не може бити, онда цар пошаље једног свог везира (Вук, Прип 25). - Кад он све чује, ражали му се здраво... Вук Прип 174.

- Кад ујутру устане, а оно виноград посађен; друго јутро лисииао - до седам дана било већ грожђе зрело... Вук Прип 114. - ...намисли да остави мужа и да бјежи овоме другоме Вук Прип 195.

(1) Презенти дводидских глагола 'виде' и 'чује' у нашим примерима означавају перфективне радње (за разлику нпр. од: - ...теби је до јела, а не вияиш где газда хоће да умре!).

(2) Слично значење имају и лексички имперфективни глаголи ‘листати' и ‘бјежати', један употребљен у перфекту, а други у презенту. 
Уведени смо у проблематику необичних значења временских глаголских облика која подразумевају некакав вид 'перфектизације', односно боље: 'глобализације' значења глагола. Да бисмо дошли до решења проблема, очито је потребно прегледати нешто ширу грађу и повести расправу о њој. У анализу ћемо узети три различите стилске формације: Вуков превод Новог завјета, Вукове Српске народне припивијетке, и Приповетке Л. Лазаревића.

\section{4. Преглед грађе из Нової завјей $а$}

1. Вуков превод Новог завјета представља један од стубова српскога књижевног језика на којима и данас почива цела његова зграда. У многим правцима овај текст је не само узорит, већ представља темељ за каснији развој свечаног стила српскога књиженог језика. То што је књижевни језик током времена непрестано напредовао и развијао се добијајући све нове и нове масе грађе и облика израза - не значи да је у тој мери превазишао полазне облике да би их ваљало заобилазити у расправи о најзначајнијим питањима српскога књижевног језика. Како у осталим доменима, тако ствар стоји и у домену употребе личних глаголских облика, и њиховим основним својствима.

2. Грађу ћемо разврстати по облицима и по видским особеностима облика.

2.1. Најзначајније су појаве у вези са аористом, а у Новом завјету је забележено и највише примера за тај облик, па ћемо кренути од њега.

a) Најчешће смо се сусретали са глаголима 'видети' и 'чути':

Каде вияјеше звијезду гдје је стала, обрадоваше се веома великом радости Мат 2/10.

И ушавши у кућу, вияјеше дијете с Маријом матером његов Глас у Рами чу се, плач и ридање, и јаукање много: Рахила плаче за својом дјецом, и не ће да се утјеши, јер их нема Мат $2 / 18$.

А кад чу Исус даје Јован предан, отиде у Галилеју Мат 4/12. 
Анализа је врлоједноставна: свуда је аорист перфективан по значењу, и означава догађај који се десио у прошлости, у познато време.

б) Издвојили смо модалне глаголе јер су о њиховим видским значењима мишљења подељена:

Дадоше му да пије оцат помијешан са жучи, и окусивши не $x \bar{u} j e$ да пије Мат 27/34.

И сабраше се око њега људи многи, тако да мора ући у лађу и сјести; а народ сав стајаше по бријегу. - И он им казива много у причама... Мат 13/2-3.

А ја вам кажем да је Илија већ дошао, и на познаше га; него учинише с њим што хйјеще... Мат 17/12.

У нашим примерима обележене форме имају перфективни смисао.

в) Слично ствар стоји и у следећим случајевима:

Тада разумјеше да не рече квасца хљебнога... Мат 16/12.

Тада разумјеше ученици да им говори за Јована крститеља Мат 17/13.

Јер дође к вама Јован путем праведнијем, и не вјеровастие му; а цариници ии курве вјероваше му... Мат 21/ 32.

...и прекори их за њихово невјерје и тврђу срца што не вјероваше онима који су га видјели да је устао Марко 16/14.

Глаголи 'разумети', 'веровати' и њима слични у самосталној употреби показују имперфективно значење, али у нашим примерима упућују не само да је радња 'целовита', него инсистирају на тренутности догађаја: 'разумјеше' значи 'постадоше свесни'; 'вјероваше' је слично као 'повероваше'.

г) Друкчији је смисао глагола 'јести’ и 'пити’:

...и преломивши даде ученицима својијем, а ученици народу.

- И јеgоше сви и настише се... Мат 14/19-20.

И јеgоше сви, и наситише се... Мат 15/37.

И узе чашу и давши хвалу даде им; и йище из ње сви Марко $14 / 23$.

Иако нам се чини да ови глаголи могу имати перфективно значење, у нашим примерима су видски неодређени: нема 
симптома за утврђивање да ли је 'једење' и 'пијење' овде трајало или је ограничено на један тренутак. Но у сваком случају се радње „сагледавају у целини свога постојања“.

д) Глагол 'бити' као једна од најупотребљивијих лексичких јединица има посебно место и у теорији о употреби облика. Располажемо са свега два примера аориста:

И он уставши узе дијете и матер његову ноћу и оде у Мисир. И $\delta$ тамо до смрти Иродове... Мат 2/15.

Тада рече слугама својијем: свадба је дакле готова, а званице не бише достојне Мат 227.

И $\delta u$ ондје дана четрдсет, и куша га сотона, и $\delta u$ са звјерињем, и анђели служаху му Марко 1/13.

Будући да је семантички недовољно 'јак', није ни његов видски идентитет јасно оцртан, како иначе, тако исто и у наша два случаја. Али је ипак јасна 'целовитост' његове реализације. У првом и потоњем примеру 'целовитост' је потврђена ограничењима која долазе од адвербијалне одредбе 'до смрти Иродове..., у првом од њих; одн. 'дана четрдесет, у другом.

ђ) Следе примери у којима аорист има недвосмислено имперфективну вредност:

Тада уставши запријети вјетровима и мору, и постаде тишина велика. - И људи чуguше се говорећи: Ко је овај да га слушају и вјетрови и море? Мат 8/ 26-27.

И сабраше се око њега људи многи, тако да мора ући у лађу и сјести; а народ сав стајаше по бријегу. - И он им казива много у причама... Мат 13/2-3.

Ови пошљедњи један сахат раgume, и изједначи их с нама који смо се читав дан мучили Мат 20/12.

И кад је излазио из Јерихона за њим uge народ многи Мат 20/29. И одмах усахну смоква. - И видјевши то ученици његови guвише се говорећи: Како одмах усахну смоква! Мат 21/19-20. А главари свештенички и старјешине и сав сабор тражаху лажна свједочанства на Исуса да би га убили. - И не нађоше, и премда многи лажни свједоци gолазише, не нађоше Мат 22/59-60.

И пљунувши нањ узеше трску и бише га по глави Мат 27/30. И одговарајући Исус рече им: Подајте ћесарово ћесару, и Божије Богу. И чуguше му се Марко 12/17. 
И они изиђоше и прповиједаше свуда, и Господ их потпомога, и ријеч йойврђива знацима Марко 15/20.

(1) Облик 'чудише се', у првом и претпоследњем примеру, стварно је имперфективан по смислу јер његова радња није ограничена на један моменат времена. Али у овом окружењу аорист не значи ни неограничено трајање, тј. не упућује да се крај и почетак губе из вида слушаоца или читаоца, већ се догађај представља као цео реализован у ситуацији о којој је реч. То значење назваћемо 'комплетним' или 'глобалним', а функцију облика 'глобализацијском' (наравно, у семантичком смислу) ${ }^{8}$.

(2) Исто и 'казива', као и сви остали овде наведени облици.

2.2. Необичне су неке употребне варијанте презента, ма да у другим правцима него аорист, па ћемо их прегледати по реду.

a) Најпре ћемо навести и покушати да разјаснимо презент глагола 'казати', који се у речницима (РМС, РСАНУ) дефинише као двовидски: „свр. и (ређе, обично у през.) несвр.“. Примери, међутим, покаазују нешто друго, врло необично:

А ја вам кажем да ће сваки који се гњеви на брата својега ни за што, бити крив суду Мат 5/22.

Заиста ти кажем не ћеш изићи оданде док не даш до пошљедњега динара Мат 5/26.

А ја вам кажем да сваки који погледа на жену са жељом, већ је учинио прељубу Мат 5/28.

А ја вам кажем да сваки који пусти жену своју, осим за прељубу, наводи је те чини прељубу Мат 5/25.

А ја вам кажем: љубите непријатеље своје Мат 5/44.

Зато вам кажем: не брините се за живот свој, шта ћете јести, или шта ћете пити Мат 6/25.

А и ја теби кажем... Мат 16/18.

8 Термин 'комплетан' и ‘комплетизација' нису згодни јер упућују на унутрашњи садржај и потпуност елемената, док наш инсистира заправо на целовитост, вањску заобљеност. 
Свудаје обликпрвог лицаједнине, исвуда даклеговорник упозорава на оно што у истим исказним формама износи. И по томе, а и по општој природи 'индикативног' презента, не би могло бити сумње да је 'кажем' имперфективни облик. Па ипак - опет не може бити сумње - да 'кажем' овде нема вредност 'казујем', већ неку другу?! А та друга јесте обухватање 'радње' као целине, без упућивања на њено трајање. Овде се не ради о значењу облика, већ о употреби глагола перфективног вида у 'глобализацијској' служби.

б) Прави двовидски глаголи понашају се по посбним законитостима које ће се препознати у следећим примерима:

А ти кад постиш, намажи главу своју и лице своје умиј. - Да те не вuge људи гдје постиш, него отац твој који је у тајности! и отац твој који виgu тајно, платиће ти јавно Мат 6/17.

Тада дође Исус из Галилеје у Јордан к Јовану да се крстии Мат 3/13.

А Јован брањаше му говорећи: Ти треба мене да крсиииш... Мат 3/14.

Кога ја ијеливам онај је.: држите га и водите га Марко 14/44.

(1) Глагол 'видети' заступљен је у првом примеру у два примерка. (а) Потоњи случај представља индикативни презент 'отац твој... види тајно' (док говор траје, свевидећи Бог посматра), и он има имперфективно значење. (б) Иако 'гдје постиш' сугерира трајање, 'да те не виде' ипак има перфективни смисао (у перспективи евентуалног остварења). Вредно је упамтити да радња посматрана у даљој перспективи захтева перфективни смисао, а она у првом плану говорне ситуације - имперфективни.

(2) Слично је значење презента 'да се крсти', 'да крстиш'. Оба имају перфективно значење у перспективи евентуалног остварења.

(3) Презент 'цјеливам' има проспективни смисао са евентуалним остварењем у будућности. И он је перфективан.

Према томе, гледано са платформе коју даје анализа ово неколико случајева - видска варијација приказаних глагоал зависи овде од 'ракурса' из којег се 'радња' приказује: са 
већих удаљења она се приказује као целовит догађај, а из ближег угла - као процес који траје.

в) Теже су објашњиви облици презента у следећим примерима:

Сједите овдје сви док ја иgем да се помолим Богу М арко 24/32. Али главари свештенички подговорише народ боље Вараву да $и ш \bar{u} y$ да им се пусти Марко 15/11.

(1) Глагол 'ићи' једнозначно је имперфективан. Овде он чак значи 'отићи и вратити се', а не односи се једноставно на акт ходања. Па ипак је перфективан по смислу. Боље је заправо рећи да има глобализацијску службу приказујући догађај из даље перспективе (Постериорност овде има смисао проспективности, или боље: упућује на планирану радњу која ће се евентуално остварити).

(2) Слична је ситуација у другом примеру, сем што је проспективност у вези са подстицајношћу.

2.3. Већ је примећено у науци да прохибитвно употребљен имперфективни облик добија перфективни смисао. Али није примећено да је и императив у ужем смислу, кад је јаче експресиван, може доживети истоврсну мутацију:

И примивши у сну заповијест да се не враћајук Ироду, другим путем отидоше у своју земљу Мат 2/12.

Ни главом својом не куни се, јер не можеш ни длаке једне бијеле или црне учинити Мат 5/36.

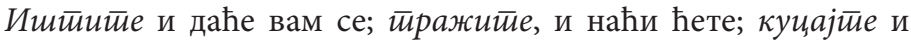
отвориће вам се Мат 7/7.

(1) Облик 'не враћајте се' - који се назире иза облика трећег лица и индиректног императива, појачајни смисао има управо у замењеној форми перфективног вида имперфективном.

(2) Слично ствар стоји и са другим примером 'не куни се'.

(3) 'Позитивно' имеративно значење по правилу оставља глагол у виду који захтева врста употребе. Међутим, и овде се осећа лак 'глобализацијски' присенак, па је осећај имперфективности тиме донекле засењен. 
2.4. Перфекат је често свјим основним смислом усмерен на постреалзацијски моменат и на 'резултат' глаголом означеног садржаја. Тако конципирано значење представља заправо повољн услова за глобализацију смисла, што се поготову очитује код двовидских глагола, али и код неких других:

Нигда се тога није вияјело у Израиљу Мат 9/33.

Чули сте како је казано старима: не чини прељубе Мат 5/27.

Јер ово је онај за кога је йисано: ето, ја шаљем анђела својега... Мат 11/10.

А кад ниче усјев и род донесе, онда се показа кукољ. - Тада дођоше слуге домаћинове и рекоше му: Господару! нијеси ли ти добро сјеме сијао на својој њиви? Откуда дакле кукољ? Мат 13/26-27.

(1) Облици 'видјело се' и 'чули сте' једнозначно показују перфективни смисао. Но та перфектиност није заправо сведена на тренутачност значења, већ на глобализацијску перспективу из које се упућује на садржај.

(2) Глобализацијска перспектива видна је и код трећег примера и облика 'писано је', иако осећај за извесно трајање 'писања' није излињао.

(3) Слично е и у '(нијеси ли) сијао’.

2.5. Инфинитив је прост назив глаголског садржаја, и ван контекста има значење вида које одговара садржају ('писати', 'ићи', 'говорити' према 'написати', 'поћи', 'рећи' итд.). Но у контексту овај облик такође може бити према свом садржају постављен из даљинске визуре, и тада је могуће да буде и он захваћен глобализацијским смислом, нпр.:

Али чувши да Архелај царује у Јудеји мјесто Ирода оца својега,

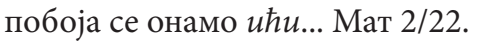

Жао ми је овога народа, јер већ три дана стоје код мене и немају шта јести и Мат 15/32.

2.6. Посебно место у оваквим разматрањима припада партиципима.

a) Прилог времена прошлог првенствено се твори од перфективних глагола, а интересантно је погледати како у 
томе стоје остали. Прво ћемо навести примере двовидских основа:

Али чувщи да Архелај царује у Јудеји мјесто Ирода оца својега, побоја се онамо ићи... Мат 2/22.

И гле, сав град изиђе на сусрет Исусу; и вияјевщи га молише да би отишао из њиховога краја Мат 8/34.

А Јован чувщи у тамници дјела Христова посла двјицу ученика својијех Мат 11/2.

И чувши ученици падоше ничице... Мат 17/6.

И одмах усахну смоква. - И вияјевщи то ученици његови дивише се говорећи: Како одмах усахну смоква! Мат 21/19-20. И чувщи дивише се, и оставивши га отидоше Мат 22/22.

(1) Облик 'чувши' у свим примерима колико их овде има означава једнократни догађај из нешто удаљеније перспективе, што погодује глобалном увиду у догађај.

(2) Исти је случај са обликом 'видјевши'.

б) Слично је и у следећим примерима:

И крстиивии се Исус изиђе одмах из воде; и гле, отворише му се небеса, и видје Духа Божијега гдје силази као голуб Мт 3/16. И Исус разумјевщи рече им... Мат 16/8.

Разумјевши Исус ликавство њихово рече... Мат 22/18.

(1) Глагол 'крстити се' припада групи двовидских (РСАНУ: „свр. и несвр.). По ономе што налазимо у нешем примеру, међутим, глагол је по вој прилици - кад се нађе ван употребе - по основном зачењу - имперфективан. У контексту какав га окружује у овдашњој ситуацији - он одаје глобализацијске особености: радњу приказује „у целини њенога постојања“.

(2) Све што је речено за претходни, важи и за случајеве са 'разумјевши'. И 'разумети' у речнику има квалификацију имперфективног и перфектиног глагола (РМС: „сврш. и несврш."), али у нашем случају само глобализацијски процес сведочи о 'перфективности'.

в) Слична нијанса смисла осетна је и код једнозначно несвршених глаг.: 
И йостиивщи се дана четрдесет и ноћи четрдесет, на пошљетку огладње Мат 4/2.

...ево сам објед свој уготовио, јунци моји и храњеници поклани су, и све је готово; дођите на свадбу. - А они не маривщи отидоше... Мат 22/ 5.

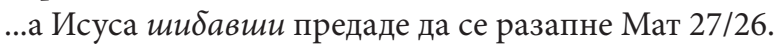

У првом примеру адвербијал 'дана четрдесет... и сам поставља оквир у којем се врши што означава глагол, али у друга два тога оквира нема, па ипак је присутна глобализацијска нијанса.

2.7. Прилог времена, садашњег, насупрот времену прошлом, интезивира значење имперфективности код глагола у основи:

А људи виgећи чудише се, и хвалише Бога, који је дао власт такову људима Мат 9/8.

Тако се народ дивљаше, виgећи нијеме гдје говоре, узете гдје здраве, хроме гдје иду, и слијепе гдје гледају; и хвалише Бога Израиљева Мат 15/31.

Одабрали смо двовидски глагол видети, и видимо да је и код њега тежња ка имперфектизацији врло јака: 'видећи' сагледавамо у току процеса.

\section{5. Грађа из Вукове збирке Срйских народних йрийовијеgака}

1. Структура исказа одговара својствима текста из којега потичу, па су број и врста примера узетих из народних приповедака друкчији него из Новог завјета. Аорист је нпр. заступљен сразмерно мало, док је презент врло чест у приповеткама, па је шире заступљен и у корпусу.

2. Иначе, понашање облика је заправо идентично у једном и другом тексту.

2.1. Аорист је забележен у следећим случајевима: 
Пошто цар виђе ђе обранио чоека, притрчи к њему... (Цар Дукљан)

Пошто вићеще да ће их опет стићи, извади царев син они орах пак завика (Ђавоља маштанија и Божја сила)

...па оде дома и покаја се и као прави Хришћанин до дубоке старости живлье (Побратимски дарови)

а) Двовидски глагол 'видети' нашао се у два примера, и оба пута има перфективно значење, у смислу како смо га запазили и у Новом завјету: радња је представљена као тренутна.

б) Аорист имперфективнога глагола 'живети' - у последњем примеру - ограничена је временском одредбом 'до дубоке старости', и тако и с те стране представљена као глобална целина.

2.2. Презент је у нашем корпусу најзаступљенији.

a) Сразмерно је најчешће бележен глагол 'казати', о којем немамо рећи ништа ново, па само још једном изражавамо сумњу у исправност мишљења да ова глаголска реч може бити имперфективна по значењу:

У том Турчин дотрчи пред воденицу... па улети у воденицу: Камо море таки и таки човек, што је сад ту ушао у воденицу? - А Еро му каже: Ено га, видиш ђе утече уз брдо (Еро с онога свијета)

...одговори да има нешто на срцу, али не сме никоме казати, „а да ми је“ вели „да комегод кажем, одмах би ми одлакнуло“. Онда му мајстор рече: „Кажи мени, ја нећу никоме казати..; ако ли не ћеш..., а ти изиђи у поље иза града, па ископај јаму те завуци главу у њу па у три пута кажи земљи шта знаш... Момак... ископа јаму, те у њу завуче главу и у три пута рекне... (У цара Тројана козје уши)

Теке се састану, ухвате једно друго за руку док се познаду и једно другом каже да се љубе... (Чудотворни нож)

б) Код двовидских глагола 'видети’ и 'чути’ презент има перфективни вид: 
„Како ћу вас ја из ковчега намирити, кад не виguм ни вас ни онога око чега се свађате“ (Соломуна проклела мати)

Кад ђаво чује сврачиј глас, он види шта је, па се брже боље врати натраг (За што људима није табан раван?)

Обазревши се да виgu ђе је ђевојка угледа је над језером ђе зраке сунчане у иглу удијева, те по ђерђеву везе на поставу којему су жице од јуначкијех перчина (Чудновата длака)

Дивљан већ виgи да му од многе стоке не може ништа... (Дивљан)

...те оде к ђевојци, али не да је проси, него само да је виgи и да је нешто пита (Лијепе хаљине много којешта чине)

Нема сумње нпр.. да је у последњем примеру 'да је види' употребљено са перфективним смислом, а тако је и у осалима.

в) И други неки глаголи имају двојако видско значење, а у нашим примерима су једнозначно перфективни:

Пошто на питање шта који има у врећи један одговори да носи на вашар орахе а други вуну, навале обојица да йазаре хеспап..., али кад виде да онај што је имао шешарице не да прида ништа..., йазаре једно за друго (Два новца)

„Е побратиме, сад да се gарујемо, ја ћу теби даровати снагу и благо, а ти мени за оба ова дара само своју душу“ (Побратимски дарови)

Облик 'пазаре' оба пута се односи на једнократна радња чије је трајање сасвим у позадини, па се представља као тренутни догађај. Исто је и са обликом '(да) се дарујемо'.

г) Слично је и у следећим примерима, али не идентично:

...те оде к ђевојци, али не да је йроси, него само да је види и да је нешто пита (Лијепе хаљине много којешта чине)

...он их сазова све у сватове, па с ђевојком дома пјевајући и лубардајући, и ту их части и пићем и јестивом (Лијепе хаљине много којешта чине)

...упази га царева шћер, уњ се смртно заљуби и рече оцу да га зове у кућу (Три јегуље)

Презенти '(да) проси', 'части', 'зове' у околностима забележених примера не негирају трајање радње, али је 
приказују у њеној целовитости, имају дакле гобалиацијски смисао.

д) Опет су за малу нијансу друкчији примери:

...она у та час напише књигу посланицу те је пошље за њим по једној највјернијој слузи, у којој му йище да сјутра у јутро рано крадом до ње дође (Чудотворни нож)

...uиนй Међедовић домаћина шта му је било ономе зубу, те је онако мимо све остале покварен (Међедовић)

...те оде к ђевојци, али не да је проси, него само да је види и да је нешто йитй (Лијепе хаљине много којешта чине)

a) Стевановић реалтивни облик презента 'пише' без резерве сматра перфективним (в. горе). Али се трајање његове радње не може превидети, а само је представљена као целовити догађај, дакле у глобалној перспективи.

б) Исто је и са презентом 'пита' у следећа два примера: 'заобљеност' догађаја не искључује његово унутрашње значење трајања.

ђ) Презент 'идем'/'иде' са проспективним смислом приказује радњу као целовит догађај (рекли смо већ да он на овај или онај начин имплицитно упућује и на повратак: опаска 'да бих се и не вратио' просто открива оно што обрт подразумева; у другима је тај моменат прекривен или сасвим ишчезао, но свеједно је потенцијално могуће раконструисати га макар као негативну нијансу):

...а ја ugeм, па ћу ући у кћер тога и тога цара (Зла жена)

„Немој плакати, мајко. Иgем ја да их тражим (Стојша и Младен)

„Богме, баба, иgем, да бих се и не вратио!“ (Ђавоља маштанија и Божја сила)

...она га упита куд uge, а он јој каже да uge просити ђевојку (Ђавоља маштанија и Божја сила) маштанија и Божја сила)

е) У случајевима које наводимо ниже глобалност садржаја само је овлаш наговештена, али ипак постоји као далики присенак значења: 
...онда Бог пошаље светог Аранђела, да ілеgа како да узме сунце од ђавола (За што људима није табан раван?)

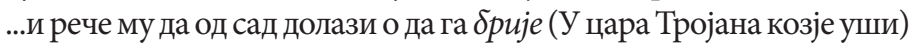
...а он му одговори да... му је цар казао да га свагда он $\delta p u j e ~(У$ цара Тројана козје уши)

Презент '(да) гледа' није далек по значењу од '(да) покуша', иако је њихова сличност прекривена другим слојевима смисла.

2.3. Забележили смо и неколика примера перфекта, па их наводимо заједно ма да не чине јединствени скуп форми у односу на нашу тему:

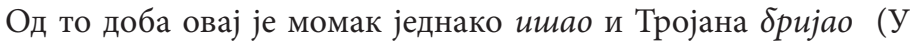
цара Тројана козје уши)

„...когод је тамо ишао да је проси, нико се није вратио“ (Ђавоља маштанија и Божја сила)

Онда се он одмах пробуди па запита слугу: „Шта је? јесу ли gолазиле?" А слуга одговори да су gолазиле и како су осам пале на језеро, а девета њему на коња, и како га је грлила и будила (Златна јабука и девет пауница)

a) Перфекти 'ишао је' и 'бријао (je)' неспорно су имперфективни по значењу. Али је догађај који описују ипак целовито приказан, дакле у перспективи глобализованости.

б) Сасвим је искључена могућност приказа радње перфекта 'долазиле су' као перфективне. Па ипак, најпре, он овде значи и одлазак, и друго, и једно и друго се приказују као јединствен догађај, дакле глобална семантичка целина.

2.4. У два случаја забележен је императив са глобалзацијским смислом у представљању догађаја:

„Не йийај ме, господару!“ (Три јегуље)

...те узми и натовари оне три коња и с њима овамо бјежи (Чудотворни нож)

Облик 'питај' или ‘бјежи' не инсистира ни у којој перспективи на трајању онога што глагол значи, већ га редставља као целовит догађај. 
2.5. Инфинитив у нашим следећим примерима двовидских глагола свој садржај представља у нешто удаљенијој перспективи у којој је трајање у позадини, а у првом плану је радња приказана као целовит догађај.

А чоек му рекне: „Бе и Брко је неки; сад ћеш га вићей $u^{“}$ (Међедовић)

„Е побратиме, сад да се дарујемо, ја ћу теби gаровай снагу и благо, а ти мени за оба ова дара само своју душу“ (Побратимски дарови)

„Ох да ми је вјенчайи ђевојку да је бијела као снијег, а румена као крв!“ (Ђавоља

2.6. И по ономе што је речено горе, а и по реалном значењу, партиципи стоје у пуном раскораку што се тиче видских значења.

a) Прилог времена прошлог обавезно има перфектизацијски, или бар глобализацијски смисао:

...и ияавщи за дуго почине под једнијем великијем каменом (Побратимски дарови)

Царев син чувши то, потрчи брже боље... (Пепељуга)

Чувши то цар Тројан одмах дозове онога берберског момка... (У цара Тројана козје уши)

б) Прилог времена садашњег, насупрот, приказује садржај глагола у његовом току чије границе никако нису назначене:

...а ђак јадни виgећи да се и њему сјутра ножић под грло справља, домисли се те они шиљак заврти дивљану у око и ослијепи га (Дивљан)

Кад ујутру сване, напипље дивљан врата од пећине и виgећи да су затворена почне по пећини брбати тамо амо, да ђака ухвати (Дивљан)

\section{6. Грађа из приповедака Лазе К. Лазаревића (имперфективни аорист и имперфекат)}

1. Већ досад анализирана грађа показује извесну правилност у понашању не само аориста, већ и презента, 
императива, партиципа прошлог и др. Та поравилност тиче се приказа радње из даљег угла као целовитог догађаја, а изблиза као процеса у току. Изузетак чини аорист, који из ближе перспективе радњу предсатвља управо као целовит догађај. Преоверићемо наше налазе тако што ћемо анализирати још и грађу из приповедака Лазе К. Лазаревића. Опште је мишљење да је Лаза К. Лазаревић писац чијем се језичком осећању не може ништа приговорити, као ни уметничком генију. Познато је исто тако да је он у неким питањима језичких вредности и језичке употребе, сем за народном речи, строго следио за језичком праксом Вука Ст. Караџића. Сем осталог - то се може устврдити и за употребу глаголски временских облика, посебно аориста и имперфекта. У овом поглављу нашег рада изложићемо грађу само ова два облика у обиму који дозвољава обим нашег рада.

2. Висока фреквенција пређашњих времена у Лазаревићеву тексту сведочи заправо о његовом избору језичких узора и стила којим је писао своје приче. По томе, а и по избору тема, схватањима која је испољавао у свом стваралаштву и моралним порукама - очигледно је да је Лаза Лазаревић у себи носио дубоко релегиозна осећања, као и високо поштовање не према Вукову делу и Вукову и Даничићеву језику као таквом, већ заправо према религијским списима, то јест конкретно према Светом писму, које се трудио да копира у многим правцима. Вратићемо се језичком изразу, и навешћемо нпр. опис двојице јунака приповетке 'Све ће то народ позлатити':

Замало још, и свет се сасвим разиђе. Осим слугу и чиновника паробродских на обали стиајаху само још два човека... Онај у фесу, Благоје казанџија - цео дан нестрпљиво хоgame: сваки час зайийкиваше кога по штогод; обрйаше се непрестано...; улажаше у станичну гостионицу, и чисто као да ће одоцнити, исиирчаваше, упирући поглед далеко преко Саве. Његово лепо избријано, чисто лице... сииајаше некако у контрасту с маленим плавим, ведрим очима које живо, па ипак с поуздањем, скакаше с једног предмета на други.

Сваки час је запиткивао..., на што му момци и агент, са 
урођеним господством страних држављана, врло кратко и осорно одіовараше 144-145.

Капетан, пак, по имену Танасије Јеличић, сйајаше готово цео дан на истом месту... Лице му беше окренуто страни с које лађа долази, а очи уморно и стално блуguше око тога места... На његову лицу не беше онога хероичнога изгледа...; све то издаваше господина и гејака... 145.

a) Наведени редови показују висок ниво приповедног инензитета са врло необичним унутрашњим односима. (1) Почетни аорист '(Замало још и свет) се (сасвим) разиђе' као да обележава дубок обрт ситуације: живост која је владала на 'пристаништу' наједном престаје, и настаје мир: 'Осим слугу и чиновника паробродских на обали стајаху само још два човека'. Али знатни таласи оног немира из претходне слике прилива се и на овукоју пратимо. (2) Између осталог томе доприноси контраст међу двојицом актера: узнемиреним и устрепталим 'Благојем казанџијом', кога не држи место и који не престаје трчкарати с места на место и запиткивати људе о доласку лађе; и мирног и забринутог 'капетана', усредсређеног на 'страни с које лађа долази'. Мноштво имперфеката сугерира унутрашње кретање које се на површини показује само као напон који најављује долазак значајних догађаја.

б) Имперфекти 'стајаху', 'стајаше,', 'беше' у тону су са сугерираним миром описане слике, али актуелност радње коју сугерирају чини да интензитет излагања одржава висок ниво. Да се подсетимо, имперфекат осветљава радњу као процес који управо тече у ситуацији на коју се односи (старији истраживачи говоре о 'доживљености', а савременији о актуелности, 'изненадности' или сл., и код аориста и имперфекта).

в) Посебно истакнути облици јесу имперфективни аористи. Већ смо се сусрели са квалификацијом њиховом као облика за 'перфектизацију', односно 'глобализацију', 'комплетизацију радње итд. И заиста, према нпр. имперфекту 'стајаше' - као облику за обележавање актуелног процеса у трајању, аорист 'скакаше' инсистира на самој ситуацији, и ограничава трајање радње на њу саму. Исто такав је однс има аорист 'блудише' према имперфекту 'стајаше'. Перфект ‘је запиткивао’ неутралан је што се тиче актуелности радње 
коју означава, али на неки начин је сличан имперфекту што се тиче трајања њеног: не упућује на границе дешавања. Аорист 'одговараше', напротив, нема уграђених 'сензора' за индикацију дешавања ван ситуације на коју се односи, па се тај факат прима као ограничавајући моменат, као приказ радње у целости њеној.

3. Имперфективни аорист не ограничава се на наведене примере, већ се јавља у већем броју:

9 Изоставили смо случајеве у којима писани текст не допушта да идентификујемо облике као аорист или имперфект. Гледајући према контексту, могло би се рећи да је у следећим случајевима употребљен аорист: Ја дођох до прозора и ілеgax је са стране 29.

Она спусти вез у крило и наслони се на руку. Ја узех ту руку и спустих је на сто, миловах је 30.

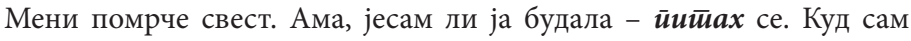
загазио? 34.

Ја откључах капију. - Она уђе тромо. Под степенима ойресаше ноге на асури, и то чињаше некако тромо. Била је веома бледа 35.

- Хоћу ја теби показати - рекох му - с киме ти мислиш да се шалиш - и још крепче га стегнух и ілеgax му у очи 48.

Ја га скопах руком за груди и грунух га о зид. Он спусти руке и ілеgаше ме блесасто. - Ја не знадох више за себе. - Лежи! - виках ја. - Он ме само блесасто гледаше 48.

Мени су зујале уши. Ја легох њој у крило. Глеgах у небо слушах крекетање жаба 52.

Пред вече устанем, отворим прозор и ілеgax у врт. Доле је вратар преривао будаком црну земљу која је распростирала око себе онај влажни пролећни мирис. Она се врати натраг у собу, а ја сйајаx на вратима. Гледам за њом - не знам шта да мислим 72.

У случајевима као следећи одређеније се може устврдити да је реч о имперфекту:

Ја луйах орахе и gвах јој, она их замакаше у мед 22.

...ми сииајасмо пред огромним парком у коме владаше пуна ноћ 32.

Моји нећаци и сестрићи клоне се тетке и ујне. Ја ілеgax само у њу. и њој беше тужно и хладно 38.

Биваше ми све нејасније, ја се ойрашйах с њоме и опет је йражих и ірлих и бехај готов да је не оставим до смрти 54.

Већ се йриближаваше Петровдан. Сваки дан иичекивасмо Марину поруку... 106.

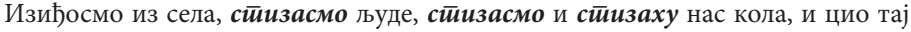
урнебес креташе се једним правцем 111.

Он гледа у нас; видело се да гледа у нас, али му поглед беще упрт за читав педаљ поврх нас. И што му се више ӥриближавасмо поглед се све више ближио тавану 161. 
Она ми изїлеgаше увређена. Не $\boldsymbol{x и ̆} е$ ништа више говорити 23. Онда уведох Ану у тај мој завичај, и цела слика потамне. Људи ме ілеgаше као странца. Мојој матери неста смеха са усана. Опет ми се ређаше слике. Опет она с црним шалом око главе 39.

Ја устадох од стола и стиах крај прозора. И други поустајаше. Сви_ћутйше 47.

Поп заћута и даде се у мисли. И владика ћути. Тако то йрaja неко вријеме, онда рече поп 94.

Ту они іоворише које о чему, а највише о путу и о Мари 97.

Чудно да млађи људи, ма колико да су вољели Мару, смайраше цијелу ствар за изгубљену 111.

Однијесмо попа његовој кући. Из уста и носа липтила му крв, а ноге висише као мртве 114.

Капетан га мирно слушаше као ону шеталицу на сахату. Ни она ни Благоје нимало му не смейаше да настави своје мисли 152.

Они брзо пређоше преко моста и склонише се у страну, правећи места осталим путницима који се іураше заједно са својим птљазима, јер још не беше ниједног кочијаша ни носача 153.

Међу путницима беше браће Руса... Они немилице gaваше 155.

Дете болова још два дана. Изїлеgаше сломљено 192.

Свуда је имперфективни аорист истога значења: има ‘глобализацијску' нијансу у означавању радње на коју се односи.

\section{7. Закључне напомене}

1. У раду смо најпре скренули пажњу на досадашње покушаје објашњења глаголског вида у српском језику, као и односа вида и времена. Затим смо обрадили грађу коју смо забележили у Светом писму, у Српским народним приповијеткама В. Ст. Караџића и Лазе К. Лзаревића, јер нам се чини да је у тим делима најлакше анализом утврдити чињенице о којима је реч.

2. Старија филолошка разматрања о виду полазе од 'пунктуалне' теорије, док новији теоретичари, одбацујући 'пунктуализам' као неадекватан појам, говоре о 
'комплетизацијском', 'глобализацијском' или сл. смислу перфективности. Показало се заправо да у језику делују двојаки механизми: поред 'пунктуализацијске' функције префикса, јавља се 'глобализацијски' смисао пеерфективности код простих глагола итд.

3. Показало се, с ти у вези, да глаголски вид у српском језику није јединствена категорија, већ се може разликовати бар тројака семантика тога комплекса: прво је прави словенски вид, друго је аспект, а треће смо назвали руским термином 'способы гагольного действия'.

4. Старији синтаксичари су приметили да аорист имперфектиних глагола име специфично значење, и објашњавали су га као 'перфектизацију', али је тешко било помирити оно што аорист значи са 'пунктуалном' теоријом вида. како се показало у анализи грађе, већи су изгледи на успех ако у објашњењу значења аориста пођемо од 'глобализацијског' принципа.

\section{Извори грађе}

Вук 1969а: Вук Ст. Караџић, Нови завјет̄ їосӣoga нашеїа Исуса Христиа, Београд: Просвета.

Вук 1969б: Вук Ст. Караџић, Срйске народне иррииовијеитке, Београд: Просвета.

Лазаревић 1963: Лаза К. Лазаревић, Приӣовет̄ке, Београд: Просвета.

РМC 1967-1976: Речник срӣскохрвайскоїа књижевноі језика, Матица српска, Нови сад.

РСАНУ 1959. и д. Речник срйскохрвайскок книжевної и наровной језика, Београд: Институт за српскохрватски/српски језик CAHУ.

РС 2007: Речник срӣскої књиженої језика, ур. Мирослав Николић, Нови Сад: Матица српска.

\section{Литература}

Агрел 1918: S. Agrell, Przedrostki postaciowe časownikov polskich, Krakow. 
Арсенијевић 2013: Б. Арсенијевић, Временско и аспектуално значење аориста, Срйски језик XVIII, 253-261.

Белић 1998: А. Белић, Оиимйа линівистиика. Изабрана gела I, Београд: Завод за уџбенике.

Белић 2000а: А Белић, Постанак прасловенске глаголске системе: Уйоредна словенска линївистиика. Изабрана gела II/1, Београд: Завод за уџбенике.

Белић 2000б: А. Белић, Словенски инјунктив у вези са постанком словеснког г лаголског вида: Уйореgна словенска линївистиика. Изабрана gела II/1, Београд: Завод за уџбенике.

Бондарко и Булањин 1967: А. Б. Бондарко, И. А. Буланин, Русский ілаїол, Ленинград: Просвщение.

Бондарко 1971: А. В. Бондарко, Виg и время русскоі̄о іллаїола, Москва: Просвещение.

Бондарко 2001: А. В. Бондарко, Принцийь функииональной ірамматиики и войросы асиектиолоіии, Москва: Эдиториал УРСС.

Вуковић 1967: Ј. Вуковић, Синйакса ілаїола, Сарајево: Завод за издавање уџбеника.

Грицкат 1957-1958: И: Грицкат, О неким видским особеностима српскохрватског глагола, Јужнословенски филолоі XX.

Грубор 1953: Ђ. Грубор, Аспектна значења, Раg Јуїославенске акаgемије знаностии и умјеитностии, 253, 255.

Енгел 1988: U. Engel, Deutsche Grammatik, Heidelberg: Julius Grooos.

Ивић М. 1977: М. Ивић, Теоријско-методолошки проблеми словенске синтаксе везани за концепт 'фактивности', Јужнословенски филолої ХХХІІІ, 1-16.

Ивић М. 1958: М. Ивић, Систем личних глаголских облика за обележавање времена у српскохрватском језику, Годишғьк Филозофскоі фокулитейа у Новом Саgу, III.

Исаченко 1960: А. В. Исаченко, Граммайический сиирой русскоі̄о языка в сойостиавлении с словацким: Морфолоіия II, Братислава: Издательство Словацкой академии наук.

Комри 1976: В. Comrie, Acpect. An Introductuon to the Ctudy of the Verbal Acpect and Related Problems, Cambridge University Press.

Маслов 1962: J. С. Маслов, Войросы ілаїолноїо вияа, Москва: Издательство иностранной литературы.

Маслов 1984: Н. Ю. Маслов, Очерки йо асиекииолоїии, Лениград: Издательство Ленинградского университета.

Паул 1958: H. Paul, Deutsche Grammatik I-IV, 4. Aufl., Halle/Saale: Max Niemeyer. 
Поповић 2007: Љ. Поповић, Когнитивни приступ категорије акционалности у словенским језицима, Научни састианак слависйа у Вукове дане 36/1, 37-51.

Станојевић 2007: В. Станојевић, Аорист у српском и француском језику, Научни састианак слависйа у Вукове дане 36/1, 123-135.

Станојевић 2013: В. Станојевић, Резултативност у садашњости у француском и српском језику, Срйски језик XVIII, 213-227.

Станојевић 2014: В. Станојевић, О аористу опет и с поводом, Срйски језик XIX, 117- 132.

Танасић 2005: С. Танасић, Синтакса глагола, у књ.: Пипер и др., Синйакса савременоїа срӣскоі језика, Институт за српски језик САНУ, Матица српска, 345-476.

Тома 2007: Paul-Louis Thomas, Ка ондређењу 'инваријанте’ гчаголског вида, Научни сасиианак славистиа у Вукове gане 36/1, 53-65.

\section{VERBAL VISION AND/OR ASPECT - LEXICICOSMENICALLY(S) AND/OR COSMETIC(S) CATEGORY(S)?}

\section{Summary}

The incentive to discuss vision and time - carried out in this paper - we found in the statements of the latest investigators of the meaning of the Serbian aorist and imperfection. At the very least, it was necessary to learn about the 'aspectology' lessons, and in the recent times of the 'exclusivity' of the Slovenian verb. We exposed the most important conceptions of this and tried to conceive them in a unique understanding of vision and / or aspect.

Key words: vision, aspect, punctuality, completeism, globalism, aorist, imperfection, perfection, imperfect. 